\title{
Beyond the Precautionary Principle
}

\section{Citation}

Cass R. Sunstein, Beyond the Precautionary Principle (John M. Olin Program in Law and Economics Working Paper No. 149, 2003).

\section{Published Version}

http://chicagounbound.uchicago.edu/law_and_economics/87/

\section{Permanent link}

http://nrs.harvard.edu/urn-3:HUL.InstRepos:12876710

\section{Terms of Use}

This article was downloaded from Harvard University's DASH repository, and is made available under the terms and conditions applicable to Other Posted Material, as set forth at http:// nrs.harvard.edu/urn-3:HUL.InstRepos:dash.current.terms-of-use\#LAA

\section{Share Your Story}

The Harvard community has made this article openly available.

Please share how this access benefits you. Submit a story.

\section{Accessibility}




\section{University of Chicago Law School Chicago Unbound}

Coase-Sandor Working Paper Series in Law and

Economics

Coase-Sandor Institute for Law and Economics

2002

\section{Beyond the Precautionary Principle}

Cass R. Sunstein

Follow this and additional works at: http://chicagounbound.uchicago.edu/law_and_economics Part of the Law Commons

\section{Recommended Citation}

Cass R. Sunstein, "Beyond the Precautionary Principle" (John M. Olin Program in Law and Economics Working Paper No. 149, 2002).

This Working Paper is brought to you for free and open access by the Coase-Sandor Institute for Law and Economics at Chicago Unbound. It has been accepted for inclusion in Coase-Sandor Working Paper Series in Law and Economics by an authorized administrator of Chicago Unbound. For more

information, please contact unbound@law.uchicago.edu. 


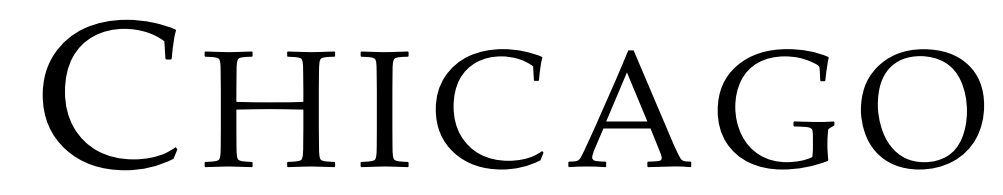

John M. Olin LaW \& ECONOMics Working Paper No. 149 (2D SERIES)

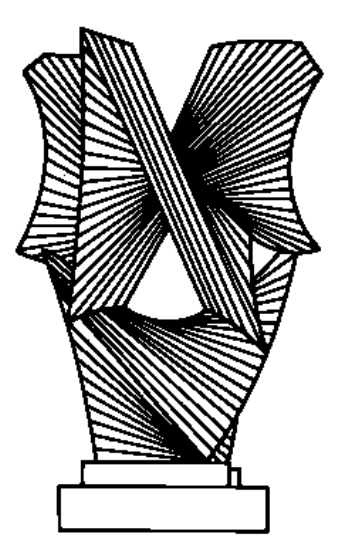

Beyond the Precautionary Principle

Cass R. Sunstein

\section{THE LAW SCHOOL THE UNIVERSITY OF CHICAGO}

Updated January 2003

This paper can be downloaded without charge at http://www.law.uchicago.edu/Lawecon/index.html

and at The Social Science Research Network Electronic Paper Collection: http://ssrn.com/abstract_id=307098 
Preliminary draft 1/12/03

All rights reserved

\title{
Beyond the Precautionary Principle
}

\author{
Cass R. Sunstein*
}

\begin{abstract}
The precautionary principle has been highly influential in legal systems all over the world. In its strongest and most distinctive forms, the principle imposes a burden of proof on those who create potential risks, and it requires regulation of activities even if it cannot be shown that those activities are likely to produce significant harms. Taken in this strong form, the precautionary principle should be rejected, not because it leads in bad directions, but because it leads in no directions at all. The principle is literally paralyzing - forbidding inaction, stringent regulation, and everything in between. The reason is that in the relevant cases, every step, including inaction, creates a risk to health, the environment, or both. This point raises a further puzzle. Why is the precautionary principle widely seen to offer real guidance? The answer lies in identifiable cognitive mechanisms emphasized by behavioral economists. In many cases, loss aversion plays a large role, accompanied by a false belief that nature is benign. Sometimes the availability heuristic is at work. Probability neglect plays a role as well. Most often, those who use the precautionary principle fall victim to what might be called "system neglect," which involves a failure to attend to the systemic effects of regulation. Examples are given from numerous areas, involving arsenic regulation, global warming and the Kyoto Protocol, nuclear power, pharmaceutical regulation, cloning, pesticide regulation, and genetic modification of food. The salutary moral and political goals of the precautionary principle should be promoted through other, more effective methods.
\end{abstract}

\footnotetext{
* Karl N. Llewellyn Distinguished Service Professor of Jurisprudence, Law School and Department of Political Science, University of Chicago. I am grateful to valuable comments from Peter Dorman, Jack Knetsch, Saul Levmore, Eric Posner, Indra Spiecker, and Adrian Vermeule, and from participants in the Midwest Faculty Seminar. I am also grateful to Martha Nussbaum for helpful discussions.
} 


\section{Introduction}

All over the world, there is increasing interest in a simple idea for the regulation of risk: In case of doubt, follow the precautionary principle. ${ }^{1}$ Avoid steps that will create a risk of harm. Until safety is established, be cautious; do not require unambiguous evidence. In a catchphrase: Better safe than sorry. In ordinary life, pleas of this kind seem quite sensible, indeed a part of ordinary human rationality. People buy smoke alarms and insurance. They wear seatbelts and motorcycle helmets, even if they are unlikely to be involved in an accident. Shouldn't the same approach be followed by rational regulators as well? Many people believe so. ${ }^{2}$

\section{A. Problems With Precautions}

I aim to challenge the precautionary principle here, not because it leads in bad directions, but because read for all that it is worth, it leads in no direction at all. The principle threatens to be paralyzing, forbidding regulation, inaction, and every step in between. ${ }^{3}$ To explain this problem very briefly, the precautionary principle provides help only if we blind ourselves to many aspects of risk-related situations and focus on a narrow subset of what is at stake. ${ }^{4}$ A significant part of my discussion will be devoted to showing why this is so. I will also urge that the precautionary principle gives the (false) appearance of being workable only because of identifiable cognitive mechanisms, which lead people to have a narrow rather than wide viewscreen. With that narrow viewscreen, it is possible to ignore, or to neglect, some of the risks that are actually at stake. I emphasize that we have good reason to endorse the goals that motivate many people to endorse the precautionary principle. These goals include the importance of protecting

\footnotetext{
${ }^{1}$ See, for general discussion, Interpreting the Precautionary Principle (Tim O'Riordan and James Cameron eds. 2002); Protecting Public Health \& the Environment: Implementing the Precautionary Principle (Carolyn Raffensberger \& Joel Tickner eds. 1999).

${ }^{2}$ See the account of widespread international support below.

${ }^{3}$ For criticisms that also emphasize the range of risks at stake, but without stressing the paralyzing quality of the principle, see Wiener, supra note; Indur Goklany, The Precautionary Principle (2001).

${ }^{4}$ For discussion of the possibly perverse effects of the precautionary principle, see Frank B. Cross, Paradoxical Perils of the Precautionary Principle, 53 Wash. \& Lee L. Rev. 851 (1996). I think that much of what Cross says is convincing, but my emphasis here is quite different: I stress the cognitive foundations of the principle and urge not that the principle leads in perverse directions but that it offers no guidance at all.
} 
health and the environment even from remote risks; the need to attend to unintended adverse effects of technological change; and the need to ensure that wealthy countries pay their fair share for environmental improvement and risk reduction. But the precautionary principle is a crude way of protecting these goals, which should be pursued directly. I do not attempt to develop any particular replacement for the precautionary principle, but I do argue on behalf of wide viewscreens in the regulation of risks.

In making these claims, I will be challenging an idea that has been a staple of regulatory policy for several decades. ${ }^{5}$ Indeed, it has been claimed that the precautionary principle has become, or at least is becoming, a binding part of customary international law. ${ }^{6}$ In the mid-1970s, German environmental policy was founded on the basis of Vorsorgeprinzip, a precursor of the precautionary principle. ${ }^{7}$ With respect to risks, German policy has been described as seeing "precaution" as a highly interventionist idea, one that embodies "a loose and open-ended interpretation of precaution." "In the United States, federal courts, without using the term explicitly, have built in a notion of precaution in some important cases, allowing or requiring regulation on the basis of conservative assumptions. ${ }^{9}$ The precautionary principle has played a significant role in international documents, to the point where it has become ubiquitous. Variations on the notion can be found in at least fourteen international documents. ${ }^{10}$ In 1982 , the United

\footnotetext{
5 For helpful discussion, see David Freestone and Ellen Hey, Origins and Development of the Precautionary Principle, in The Precautionary Principle and International Law 3 (David Freestone and Ellen Hey eds. 1994); Jonathan Wiener, Precaution in a Multirisk World, in The Risk Assessment of Environmental and Human Health Hazards (Dennis D. Paustenbach, ed., 2d ed., 2002, forthcoming).

${ }^{6}$ See O. McIntyre and T. Mosedale, The Precautionary Principle as a Norm of Customary International Law, 9 J Env Law 221 (1997); see generally Arie Trouwborst, Evolution and Status of the Precautionary Principle in International Law (2002).

${ }^{7}$ Julian Morris, Defining the Precautionary Principle, in Risk and the Precautionary Principle 1, 1 (Julian Morris ed. 2001).

${ }^{8}$ See Interpreting the Precautionary Principle (T. O'Riordan and J. Cameron eds. 1994).

${ }^{9}$ See, e.g., American Trucking Association v. EPA, F.3d (DC Cir 2002); Lead Industries v. EPA, 647 F.2d 1130 (DC Cir 1980).

${ }^{10}$ See Indur Goklany, The Precautionary Principle 3 (2001). Indeed there appears to be a cascade effect here, with informational and reputational influences leading to many casual uses of the precautionary principle, to the point where a failure to incorporate the principle would seem to be a radical statement. Simply because the precautionary principle has been used so often, those involved in international agreements are likely to believe that it is probably sensible to use it yet again. And because so many people identify the precautionary principle with a serious commitment to environmental protection, see, e.g., Protecting Public Health \& the Environment, supra note, any nation that rejects the principle risks incurring international opprobrium. For a general treatment of informational cascades, in which decisions by others
} 
Nations World Charter for Nature apparently gave the first international recognition to the principle, suggesting that when "potential adverse effects are not fully understood, the activities should not proceed." 11 The closing Ministerial Declaration from the United Nations Economic Conference for Europe in 1990 asserts, "In order to achieve sustainable development, policies must be based on the precautionary principle. . . . Where there are threats of serious or irreversible damage, lack of full scientific certainty should not be used as a reason for postponing measures to prevent environmental degradation." 12

The widely publicized Wingspread Declaration, from a meeting of environmentalists in 1998, goes further still: "When an activity raises threats of harm to human health or the environment, precautionary measures should be taken even if some cause and effect relationships are not established scientifically. In this context the proponent of the activity, rather than the public, should bear the burden of proof." ${ }^{13}$ The European Union treaty states that on the environment, EU policy "shall be based on the precautionary principle." ${ }^{\prime 14}$ Notwithstanding official American ambivalence about the principle, ${ }^{15}$ there are unmistakable echoes of the principle in American environmental law. ${ }^{16}$ The precautionary principle has received a high-profile endorsement in the New York Times Magazine, which listed the principle as one of the most important ideas of 2001. ${ }^{17}$ In February 2002, the precautionary principle was explicitly adopted by the European Commission, together with implementing guidelines. ${ }^{18}$

convey information about what it makes sense to do, see David Hirschleifer, The Blind Leading the Blind: Social Influence, Fads, and Informational Cascades, in The New Economics of Human Behavior 188, 189 (Mariano Tommasi and Kathryn Ierulli eds 1995). On reputational pressures, see Timur Kuran, Public Lies, Private Truths (1996).

${ }^{11}$ Goklany, supra note, at 4.

${ }^{12}$ Id. at 5.

${ }^{13} \mathrm{Id}$.

${ }^{14}$ European Union Treaty, article 130R (1993), currently Article 174.

${ }^{15}$ See John Graham, The Role of Precaution and Risk Assessment in Risk Managament: An American's View (2002), available at http://www.whitehouse.gov/omb/inforeg/eu_speech.html; Wiener, supra note.

${ }^{16}$ Seethe reference to an "adequate margin of safety" in the Clean Air Act, section 109, 42 USC 7409(b(1).

${ }^{17}$ The Year in Ideas: A to Z, New York Times, December 9, 2001, p. 92, column 2.

${ }^{18} \mathrm{http}: / /$ europa.eu.int/comm/dgs/health_consumer/library/press/press 38 _en.html 
In many ways the precautionary principle seems quite sensible, even appealing. To justify regulation, a certainty of harm should not be required; a risk, even a low one, may well be enough. It makes sense to expend resources to prevent a small chance of disaster; consider the high costs, pecuniary and otherwise, that are spent to reduce the risk of terrorist attack. On reasonable assumptions, these costs are worth incurring even if the probability of harm, in individual cases or even in the aggregate, is relatively low. The precautionary principle might well be seen as a plea for a kind of regulatory insurance. Certainly the principle might do some real-world good, spurring them to attend to neglected problems. Nonetheless, I will be urging that the principle cannot be fully defended in these ways, simply because risks are on all sides of social situations. Any effort to be universally precautionary will be paralyzing, forbidding every imaginable step, including no step at all.

\section{B. Precautions and Rationality}

But if the precautionary principle, taken in a strong form, is unhelpful, in a way literally senseless, how can we account for its extraordinary influence, and indeed for the widespread belief that it can and should guide regulatory judgments? I have mentioned its possible pragmatic value. And undoubtedly the principle is invoked strategically by selfinterested political actors, with European farmers, for example, invoking the idea of precaution to stifle American competitors, who are far more likely to rely on genetically modified crops. ${ }^{19}$ But apart from this point, I suggest that an understanding of human rationality and cognition provides five useful clues.

1. Loss aversion. The precautionary principle often seems appealing because of loss aversion. The central point here is that people dislike losses far more than they like corresponding gains. ${ }^{20}$ The result is that out-of-pocket costs, or deterioration from the status quo, seem much worse than opportunity costs, or benefits lost as a result of continuing the status quo. In the context of risks, people tend to focus on

\footnotetext{
${ }^{19}$ See Timur Kuran and Cass R. Sunstein, Availability Cascades and Risk Regulation, 51 Stan L Rev 683 (1999).

${ }^{20}$ See Richard Thaler, Quasi-Rational Economics (1995).
} 
the losses that are associated with some activity or hazard, and to disregard the gains that might be associated with that activity or hazard. The precautionary principle often becomes operational only because of loss aversion, as people take precautions against potential losses from the status quo, but neglect potential benefits that would be unmistakable gains. A closely related point is that unfamiliar risks produce far more concern than familiar ones, even if the latter are statistically larger; and the precautionary principle, in practice, is much affected by this fact.

2. The myth of a benevolent nature. Loss aversion is often accompanied by a mistaken belief that nature is essentially benign, ${ }^{21}$ leading people to think that safety and health are generally at risk only or mostly as a result of human intervention. A belief in the relative safety of nature and the relative risk of new technologies often informs the precautionary principle.

3. The availability heuristic. It is well known that people focus on some risks simply because they are cognitively "available," whereas other risks are not. ${ }^{22}$ When the precautionary principle seems to require stringent controls on one risk, even though other risks are in the vicinity, the availability heuristic is a common reason. And when the availability heuristic is at work, certain hazards will stand out whether or not they are not statistically large. ${ }^{23}$ The hazards associated with heat waves, for example, receive little public attention, while the hazards associated with air travel are a significant source of public concern ${ }^{24}$; one reason is that the latter hazards come readily to mind.

4. Probability neglect. People are sometimes prone to neglect the probability that a bad outcome will occur; they focus instead on the outcome itself. ${ }^{25}$ The precautionary principle often embodies a form of probability neglect. At least this is so when people invoke the precautionary principle to favor stringent controls on

\footnotetext{
${ }^{21}$ See generally James P. Collman, Naturally Dangerous (2001).

${ }^{22}$ Amos Tversky and Daniel Kahneman, Judgment Under Uncertainty: Heuristics and Biases, in Daniel Kahneman, Paul Slovic, and Amos Tversky, Judgment Under Uncertainty: Heuristics and Biases 3, 11-14 (1982).

${ }^{23}$ Paul Slovic, The Perception of Risk 40 (2000).

${ }^{24}$ See Eric Klinenberg, Heat Wave: A Social Autopsy of Disaster in Chicago (2002).

${ }^{25}$ Yuval Rottenstreich and Christopher Hsee, Money, Kisses, and Electric Shocks: On the Affective Psychology of Risk, 12 Psych Science 185, 188 (2001).
} 
a low-probability risk, when the consequence of those very controls is to give rise to new risks of equal or greater probability. ${ }^{26}$

5. System neglect. The precautionary principle often reflects a general neglect of the systemic effects of regulation. ${ }^{27}$ When a single problem is placed in view, it can be difficult to see the full consequences of legal interventions. Sometimes the precautionary principle has the appearance of being workable only because a subset of the relevant effects are "on screen"-and hence there seems to be no need to take precautions against other possible adverse effects, also involving health and safety, that do not register. An important aspect of system neglect is tradeoff neglect, one source of the conflict between experts and ordinary people in thinking about risks. ${ }^{28}$ When experts disagree with ordinary people about risks, it is sometimes because experts look at both the benefits and the harms associated with the relevant practice, whereas ordinary people are paying attention to the harms but not the benefits. ${ }^{29}$ I suggest that the precautionary principle seems appealing, to ordinary people, in large part for the same reason.

One of my major goals is show that the precautionary principle can be made workable only through routes of this kind. An understanding of behavioral economics simultaneously sheds light on the operation of the principle, explains its otherwise puzzling appeal, and suggests why it should be abandoned or at least substantially recast. Indeed, such an understanding provides a better understanding of the uses and pitfalls of the old adage, "better safe than sorry," which is subject to many of the same objections as the precautionary principle. I do not attempt to identify a competing principle for adoption by sensible regulators. But I do urge that such regulators should use a wide rather than narrow viewscreen - and that as applied, the precautionary principle is defective precisely because it runs afoul of this idea. To be sure, many of those who endorse the principle seek to protect against neglect of the future, disregard of the

\footnotetext{
${ }^{26}$ In some cases, this is a reasonable reading of the evidence governing genetically modified food. See Alan McHughen, Pandora's Picnic Basket 230-42 (2000); note in particular the evidence of harms from organic foods, discussed in id.

${ }^{27}$ See Dietrich Dorner, The Logic of Failure 6-42 (1996).

${ }^{28}$ The conflict is treated in Paul Slovic, The Perception of Risk (2000).

${ }^{29}$ See Howard Margolis, Dealing With Risk (1996).
} 
interests of those suffering from the greatest deprivation, and impossible demands for unambiguous evidence from regulators. But as we shall see, the precautionary principle is a crude and sometimes perverse way of promoting those goals, which can be obtained through other, better routes. A major purpose of this Essay is to suggest the need to use more direct effective strategies to pursue the salutary goals of risk regulation.

This Article comes in four parts. Part I briefly traces the nature and the appeal of the precautionary principle. Part II explains why the principle is paralyzing, with particular reference to the issues raised by arsenic, global warming, nuclear power, and genetic engineering of food. Part III suggests that the apparent sense of the principle is best understood in light of the behavioral points just mentioned. Part IV is a brief conclusion, in the form of a plea for wider viewscreens.

\section{The Precautionary Principle: Definition and Appeal}

I have said that the precautionary principle enjoys widespread international support. ${ }^{30}$ But what does the principle mean or require? There are numerous definitions, and they are not compatible with one another. ${ }^{31}$ We can imagine a continuum of understandings. At one extreme are weak versions to which no reasonable person could object; at the other extreme are strong versions that would appear to call for a fundamental rethinking of regulatory policy.

The most cautious and weak versions suggest, quite sensibly, that a lack of decisive evidence of harm should not be a ground for refusing to regulate. Regulation might be justified even if we cannot establish a definite connection between, for example, low-level exposures to certain carcinogens and adverse effects on human health. Thus the 1992 Rio Declaration states, "Where there are threats of serious or irreversible damage, lack of full scientific certainty shall not be used as a reason for postponing cost-effective

\footnotetext{
${ }^{30}$ See Arie Trouwborst, Evolution and Status of the Precautionary Principle in International Law (2002).

${ }^{31}$ See Julian Morris, Defining the Precautionary Principle, in Risk and the Precautionary Principle, supra, at 1-19; Wiener, supra note.
} 
measures to prevent environmental degradation." 32 The Ministerial Declaration of the Second International Conference on the Protection of the North Sea, held in London in 1987, is in the same vein: "Accepting that in order to protect the North Sea from possibly damaging effects of the most dangerous substances, a precautionary principle is necessary which may require action to control inputs of such substances even before a causal link has been established by absolutely clear scientific evidence." ${ }^{33}$ Similarly, the United Nations Framework Convention on Climate Change offers cautious language: "Where there are threats of serious or irreversible damage, lack of full scientific certainty should not be used as a reason for postponing [regulatory] measures, taking into account that policies and measures to deal with climate change should be cost-effective so as to ensure global benefits at the lowest possible cost."34

The Wingspread Declaration goes somewhat further: "When an activity raises threats of harm to human health or the environment, precautionary measures should be taken even if some cause and effect relationships are not fully established scientifically. In this context the proponent of an activity, rather than the public, should bear the burden of proof." ${ }^{35}$ The first sentence just quoted is a mildly more aggressive version of the statement from the Rio Declaration. It is more aggressive because it is not limited to threats of serious or irreversible damage. But in reversing the burden of proof, the second sentence goes further still. ${ }^{36}$ Of course everything depends on what those with the burden of proof must show in particular.

In Europe, the precautionary principle is understood in a still stronger way, suggesting that it is important to build "a margin of safety into all decision making." 37 According to one definition, the precautionary principle means "that action should be taken to correct a problem as soon as there is evidence that harm may occur, not after the

\footnotetext{
${ }^{32}$ Quoted in Bjorn Lomborg The Skeptical Environmentalist 347 (2001).

${ }^{33}$ Quoted in Rethinking Risk and the Precautionary Principle 3, Julian Morris ed. (2000).

${ }^{34}$ See Goklany, supra note, at 6.

${ }^{35}$ See http://www.monitor.net/rachel/r586.html

${ }^{36}$ See the discussion in Wiener, supra note; David Pearce, The Preconditions for Achieving Consensus in the Context of Technological Risk, in Technological Risk: Its Perception and Handling in the European Community (M. Dierkes et al. eds 1980).

${ }^{37}$ See Bjorn Lomborg The Skeptical Environmentalist 348 (2001).
} 
harm has already occurred. ${ }^{23}$ In a comparably strong version, it is said that "the precautionary principle mandates that when there is a risk of significant health or environmental damage to others or to future generations, and when there is scientific uncertainty as to the nature of that damage or the likelihood of the risk, then decisions should be made so as to prevent such activities from being conducted unless and until scientific evidence shows that the damage will not occur." ${ }^{\text {39 }}$ The Cartagena Protocol on Biosafety to the Convention on Biological Diversity, adopted in 2000, appears to adopt a strong version as well. ${ }^{40}$ The Final Declaration of the First European "Seas At Risk" conference says that if "the 'worst case scenario' for a certain activity is serious enough then even a small amount of doubt as to the safety of that activity is sufficient to stop it taking place. ${ }^{, 41}$

Professor Richard Stewart usefully distinguishes among four different versions of the precautionary principle, capturing both weak and strong types ${ }^{42}$; I paraphrase his typology here:

1. Nonpreclusion Precautionary Principle: Regulation should not be precluded by the absence of scientific uncertainty about activities that pose a risk of substantial harm.

2. Margin of Safety Precautionary Principle: Regulation should include a margin of safety, limiting activities below the level at which adverse effects have not been found or predicted.

3. Best Available Technology Precautionary Principle: Best available technology requirements should be imposed on activities that pose an uncertain potential to create substantial harm, unless those in favor of those activities can show that they present no appreciable risk.

\footnotetext{
${ }^{38} \mathrm{http}: / /$ www.logophilia.com/WordSpy/precautionaryprinciple.asp

${ }^{39}$ Testimony of Dr. Brent Blackwelder, President, Friends of the Earth, before the Senate Appropriate Committee, Subcommittee on Labor, Health and Human Services (Jan. 24, 2002).

${ }^{40}$ See Goklany, supra note, at 6.

${ }^{41}$ Final Declaration of the First European "Seas At Risk" Conference, Annex 1, Copenhagen, 1994.

${ }^{42}$ Richard B. Stewart, Environmental Regulatory Decision Making Under Uncertainty, 20 Research in Law and Economics 71, 76 (2002).
} 
4. Prohibitory Precautionary Principle: Prohibitions should be imposed on activities that have an uncertain potential to impose substantial harm, unless those in favor of those activities can show that they present no appreciable risk.

This account shows that the precautionary principle might be described both in terms of the level of uncertainty that triggers a regulatory response and in terms of the tool that will be chosen in the face of uncertainty (as in the case of technological requirements or prohibitions). With an appreciation of this point, we can easily imagine many other variations on these themes. For example, an Information Disclosure Precautionary Principle might say that in the face of uncertainty, those who subject people to potential risks must disclose relevant information to those so subjected. The debate over labeling genetically modified organism can be seen as a debate over this form of the precautionary principle. ${ }^{43}$ For every regulatory tool, there is a corresponding precautionary principle ${ }^{44}$ with possible matches or mismatches between the problem that causes for precautions and the chosen tool. ${ }^{45}$ The idea of "margin of safety" can be understood in multiple different ways, with a continuum from a small margin, designed to counteract likely risks, to a small one, designed to prevent worst cases.

The official account in Europe is very much in favor of one or another version of the precautionary principle, with the European Commission having formally adopted it. ${ }^{46}$ But European practice is far more complex, with the precautionary principle being invoked against some risks but not against others. ${ }^{47}$ To take just one example, "Europe has been more precautionary about hormones in beef, while the US has been more precautionary about mad cow disease (BSE) in beef and blood donations." ${ }^{, 4}$ While

\footnotetext{
${ }^{43}$ See Alan McHughen, Pandora's Picnic Basket 201-29 (2000).

${ }^{44}$ For discussions of regulatory tools, see Stephen Breyer, Regulation and its Reform 36-183 (1982); Cass R. Sunstein, Risk and Reason 251-88 (2002).

${ }^{45}$ On mismatch, see Breyer, supra, at 191-96.

${ }^{46}$ European Commission, Communication from the Commission on the Precautionary Principle, COM (200)!, Brussels, 2 Feb. 2000 (available at http://europa.eu.int/comm/dgs/health_consumer/library/pub/pub7_en.pdf

${ }^{47}$ See the illuminating discussion in Jonathan Wiener and Michael Rogers, Comparing Precaution in the United States and Europe, 5 J Risk Research 317 (2002).

${ }^{48}$ Id. at 323.
} 
European nations have taken a highly precautionary approach to genetically modified foods,${ }^{49}$ the United States has been especially willing to control the risks associated with carcinogens in food additives. ${ }^{50}$ In the context of occupational risk, American law is far more precautionary than Swedish law. ${ }^{51}$ I cannot venture a survey here, but it is reasonable to speculate that in actual practice, nations cannot plausibly be ranked along some continuum of precaution. More plausibly, some nations are precautionary about some risks but not others, and a general adoption of the precautionary principle will conceal this inevitable fact. ${ }^{52}$ I will return to this point and to its inevitability below, because it is closely connected to my central claims here. Nonetheless, the mounting importance of the principle in Europe deserves close attention, if only because the idea of precaution is playing such a large role in public debates.

I have suggested that the weak versions of the precautionary principle are unobjectionable and important. Every day, people take steps (and incur costs) to avoid hazards that are far from certain. We do not walk in moderately dangerous areas at night; we exercise; we buy smoke detectors; we buckle our seatbelts; we might even avoid fatty foods. Sensible governments are willing to consider regulation of risks that, in individual cases or even in the aggregate, have a well under $100 \%$ chance of coming to fruition. The weak versions of the precautionary principle state a truism-uncontroversial and necessary only to combat public confusion or the self-interested claims of private groups demanding unambiguous evidence of harm, which no rational society requires. This function should not be trivialized. Nearly a fifth of Americans, for example, recently agreed that "until we are sure that global warming is really a problem, we should not take

\footnotetext{
${ }^{49}$ See David Vogel, The Regulation of GMOs in Europe and the United States: A Case-Study of Contemporary European Regulatory Politics (Publication of the Study Group on Trade, Science and Genetically Modified Foods, 2001), available at http://www.cfr.org/pubs/Victor_ModFood_Paper2.html; Symposium, Are the US and Europe Heading for a Food Fight Over Genetically Modified Food? (2001), available at http://pewagbiotech.org/events/1024/; TonyGilland, Precaution, GM Crops, and Farmland Birds, in Rethinking Risk and the Precautionary Principle 84, 84-88 (Julian Morris ed. 2001).

${ }^{50}$ See Richard Merrill, FDA's Implementation of the Delaney Clause: Repudiation of Congressional Choice or Reasoned Adaptation to Scientific Progress?, 5 Yale J. on Reg. 1 (1988).

${ }^{51}$ See Steven Kelman, Regulating America, Regulating Sweden: A Comparative Study of Occupational Safety and Health Policy (1981).

${ }^{52}$ See Wiener and Rogers, supra note.
} 
any steps that would have economic costs." ${ }^{, 53}$ Sometimes people do seem to seek certainty before showing a willingness to expend costs, and well-organized private groups like to exploit this fact. Insofar as the precautionary principle counteracts the tendency to demand certainty, it should be approved.

Because the weak versions are sensible, I will not discuss them here. Instead I will understand the principle in a strong way, to suggest that regulation is required whenever there is a possible risk to health, safety, or the environment, even if the supporting evidence is speculative and even if the economic costs of regulation are high. To avoid palpable absurdity, the idea of "possible risk" will be understood to require a certain threshold of scientific plausibility. To support regulation, no one thinks that it is enough if someone, somewhere, urges that a risk is worth taking seriously. But under the precautionary principle as I shall understand it, the threshold burden is minimal, and once it is met, there is something like a presumption in favor of stringent regulatory controls. I believe that this understanding of the precautionary principle fits with the understandings of its most enthusiastic proponents, ${ }^{54}$ and that with relatively modest variations, this understanding fits with many of the legal formulations as well. ${ }^{55}$

Why might the precautionary principle, understood in this strong sense, have such widespread appeal? At first glance, the answer is simple, for the principle contains some important truth. Sometimes it is much better to be safe than sorry. Certainly we should acknowledge that a small probability (say, 1 in 100,000) of a serious harm (say, 100,000 deaths) deserves extremely serious attention. It is worthwhile to spend a lot of money to eliminate that risk. The fact that a danger is unlikely to materialize is hardly a decisive objection to regulatory controls. Now an economically oriented critic might observe that our resources are limited and that if we spend large amounts of resources on highly speculative harms, we will not be allocating those resources wisely. In fact this is the

${ }^{53}$ See http://www.pipa.org/OnlineReports/GlobalWarming/buenos_aires.html\#1

${ }^{54}$ See the essays in Protecting Public Health \& the Environment : Implementing the Precautionary Principle, Carolyn Raffensberger \& Joel Tickner eds. (1999).

${ }^{55}$ See Lothar Gundling, The Status in International Law of the Principle of Precautionary Action, 5 Intl J. Estuarine and Coastal Law 23, 26 (1990). 
simplest criticism of the precautionary principle ${ }^{56}$ Unless the harm would be truly catastrophic, a huge investment makes no sense for a harm that has a 1 in 1 billion chance of occurring. Taken for all that it is worth, the precautionary principle might seem to require indefensibly huge expenditures, exhausting our budget well before the menu of options could be thoroughly consulted.$^{57}$ If we take costly steps to address all risks, however improbable they are, we will quickly impoverish ourselves. On this view, the principle "would make for a dim future." ${ }^{~} 58$ This is no less true for nations than for individuals.

Some version of this argument is surely convincing, but it also seems to be missing something about human cognition. ${ }^{59}$ In some contexts, regulation is indeed a form of insurance, or a way of placing special locks on a door. Consider the following choice. Would you rather have

1. A sure loss of $\$ 20$, or

2. A $1 \%$ chance of losing $\$ 1980$ ?

In terms of expected value, (b), representing a statistical loss of $\$ 19.80$, is a bit less bad than (a); but most people would gladly choose the sure loss of $\$ 20 .{ }^{60}$ People do not like to run a small risk of a large or catastrophic loss; this is why people buy insurance and take special precautions against serious harms, even in circumstances in which an analysis of expected value would not justify these steps. ${ }^{61}$ If government follows the judgments of ordinary people, it will be risk-averse in this sense as well. The willingness to incur sure losses, in preference to low-probability catastrophes of lower

\footnotetext{
${ }^{56}$ See Graham, supra note.

${ }^{57}$ See Bjorn Lomborg, supra note, at 349.

${ }^{58}$ See Julian Morris, Defining the Precautionary Principle, in Risk and the Precautionary Principle, supra, at $1,17$.

${ }^{59}$ See Daniel Kahneman and Amos Tversky, Prospect Theory: An Analysis of Decision Under Risk, in Choices, Values, and Frames 17 (Daniel Kahneman and Amos Tversky eds. 2001).

${ }^{60}$ Id.

${ }^{61}$ A lucid discussion, with applications to litigation, is Chris Guthrie, Framing Frivolous Litigation, $67 \mathrm{U}$. Chi. L. Rev. 163 (2000).
} 
expected value, helps explain decisions in a variety of domains, involving both law and politics, including foreign policy. ${ }^{62}$

This point about judgment under risk might seem to suggest that a democratic society, following popular views, will depart from the predictions of expected utility theory and even embody a form of risk aversion for low-probability catastrophes. ${ }^{63}$ The result will be to move regulation in the direction suggested by the precautionary principle. But prospect theory cannot provide a defense of the principle in its strong form. I now explain why this is so.

\section{Why the Precautionary Principle Is Paralyzing}

\section{A. The Problem}

The most serious problem with the precautionary principle is that it offers no guidance - not that it is wrong, but that it forbids all courses of action, including inaction. To understand this point, it will be useful to anchor the discussion in some concrete problems:

1. One of the most controversial environmental issues faced in the first year of the Bush administration involved the regulation of arsenic. ${ }^{64}$ There is a serious dispute over the precise level of risks posed by low levels of arsenic in drinking water, but on the "worst case" scenario, over one hundred lives might be lost each year as a result of the 50 part per billion standard that the Clinton Administration sought to revise. ${ }^{65}$ At the same time, the proposed $10 \mathrm{ppb}$

\footnotetext{
${ }^{62}$ See id; Rose McDermott, Risk-Taking in International Politics: Prospect Theory in American Foreign Policy (1998).

${ }^{63}$ See Roger Noll and James Krier, Some Implications of Cognitive Psychology for Risk Regulation, $19 \mathrm{~J}$. Legal Stud. 747 (1990).

${ }^{64}$ Robert K. Musil, Arsenic on Tap, N.Y. TIMES, Apr. 24, 2001, at A18.

${ }^{65}$ See Cass R. Sunstein, The Arithmetic of Arsenic, Geo. L. J. (forthcoming 2002).
} 
standard would cost over $\$ 200$ million each year, and it is possible that it would save as few as six lives annually. ${ }^{66}$

2. Genetic modification of food has become a widespread practice. ${ }^{67}$ But the risks of that practice are not known with precision. ${ }^{68}$ Some people fear that genetic modification will result in serious ecological harm and large risks to human health. ${ }^{69}$

3. Scientists are not in accord about the dangers associated with global warming, ${ }^{70}$ but there is general agreement that global warming is in fact occurring. ${ }^{71}$ It is possible that global warming will produce, by 2100 , a mean temperature increase of 4.5 degrees $C^{72}$; that it will result in well over $\$ 5$ trillion in annual monetized $\operatorname{costs}^{73}$; and that it will also produce a significant number of deaths from malaria. The Kyoto Protocol would require most industrialized nations to reduce greenhouse gas emissions to $92 \%-94 \%$ of 1990 levels. $^{74}$

4. Many people fear nuclear power, on the ground that nuclear power plants raise various health and safety issues, including some possibility of catastrophe. ${ }^{75}$ But if a nation does not rely on nuclear power, it is likely to rely instead on fossil fuels, and in particular on coal-fired power plants. ${ }^{76} \mathrm{Such}$ plants create risks of their own, including risks associated with global warming. China, for example, has relied on nuclear energy in part as a way of reducing greenhouse gases and in part as a way of reducing other air pollution problems. $^{77}$

\footnotetext{
${ }^{66}$ See id,

${ }^{67}$ Alan McHughen, Pandora's Picnic Basket (2001).

${ }^{68}$ See id.

${ }^{69}$ See Tony Gilland, Precaution, GM Crops and Farmland Birds, in Rethinking Risk and the Precautionary Principle, supra note, at 60 .

${ }^{70}$ See Bjorn Lomborg, The Skeptical Environmentalist (2001).

${ }^{71} \mathrm{Id}$.

${ }^{72}$ Id. at 317.

${ }^{73} \mathrm{Id}$.

${ }^{74}$ See Robert Percival et al., Environmental Regulation 1141 (3d ed. 2000).

${ }^{75}$ See Robert Goodin, No Moral Nukes, 90 Ethics (1980).

${ }^{76}$ See Stephen Breyer, Vermont Yankee and the Courts' Role in the Nuclear Energy Controversy, 91 Harv L Rev 1833, 1835-36 (1978).

${ }^{77}$ See Note, Nuclear Energy: China's Approach Towards Addressing Global Warming, 12 Geo. Int'l Envtl. L. Rev. 493 (2000). Of course it is possible to urge that nations should reduce reliance on either coal-fired
} 
5. There is a possible conflict between the protection of marine mammals and military exercises. The United States Navy, for example, engages in many such exercises, and it is possible that marine mammals will be threatened as a result. Military activities in the oceans might well cause significant harm; but a decision to suspend those activities, in cases involving potential harm, might also endanger military preparedness. ${ }^{78}$

In these cases, what kind of guidance is provided by the precautionary principle? It is tempting to say, as is in fact standard, that the principle calls for strong controls on arsenic, on genetic engineering of food, on greenhouse gases, on threats to marine mammals, and on nuclear power. ${ }^{79}$ In all of these cases, there is a possibility of serious harms, and no authoritative scientific evidence suggests that the possibility is close to zero. If the burden of proof is on the proponent of the activity or processes in question, the precautionary principle would seem to impose a burden of proof that cannot be met. Put to one side the question whether the precautionary principle, understood to compel stringent regulation in these cases, is sensible. Let us ask a more fundamental question: Is that more stringent regulation therefore compelled by the precautionary principle?

The answer is that it is not. In some of these cases, it should be easy to see that in its own way, stringent regulation would actually run afoul of the precautionary principle. The simplest reason is that such regulation might well deprive society of significant benefits, and for that reason produce a large number of deaths that would otherwise not occur. In some cases, regulation eliminates the "opportunity benefits" of a process or activity, and thus causes preventable deaths. ${ }^{80}$ If this is so, regulation is hardly precautionary. The most familiar cases involve the "drug lag," produced by a highly

\footnotetext{
power plants or nuclear power, and move instead toward environmentally preferred alternatives, such as solar power. For general discussion, see Godfrey Boyle, Renewable Energy: Power for Sustainable Future (1996); Allan Collinson, Renewable Energy (1991); Dan E. Arvizu, Advanced Energy Technology and Climate Change Policy Implications, 2 Fl. Coastal L.J. 435 (2001). But these alternatives pose problems of their own, involving feasibility and expense. See Lomborg, supra note, at 118-48.

${ }^{78}$ See Testimony of Vice Admiral Charles W. Moore, Deputy Chief of Naval Operations for Readiness and Logistics, before the Committee on House Resources, Subcommittee on Fisheries Conservation, Wildlife and Oceans (June 13, 2002).

${ }^{79} \mathrm{See}$ http://www.inra.fr/Internet/Produits/dpenv/som-ec43.html.

${ }^{80}$ See Aaron Wildavsky, Searching for Safety (1994).
} 
precautionary approach to the introduction of new medicines and drugs into the market. ${ }^{81}$ If a government takes such an approach, it might protect people against harms from inadequately tested drugs; but it will also prevent people from receiving potential beneits from those very drugs. ${ }^{82}$ Is it "precautionary" to require extensive premarketing testing, or to do the opposite?

Or consider the case of genetic modification of food. Many people believe that a failure to allow genetic modification might well result in numerous deaths, and a small probability of many more. ${ }^{83}$ The reason is that genetic modification holds out the promise of producing food that is both cheaper and healthier-resulting, for example, in "golden rice," which might have large benefits in developing countries. ${ }^{84}$ Now the point is not that genetic modification will definitely have those benefits, or that the benefits of genetic modification outweigh the risks. The point is only that if the precautionary principle is taken literally, it is offended by regulation as well as by nonregulation. So too for regulation of ground-level ozone. Such regulation does seem justified by the precautionary principle, for responsible people believe that low levels of ozone produce a range of health harms, including risks of death. ${ }^{85}$ But there is also evidence that groundlevel ozone produces health benefits, by reducing risks of cataracts and skin cancer. ${ }^{86}$ Because the precautionary principle calls for protection when causal connections are unclear, it would appear to require, with respect to ground-level ozone, both stringent regulation and no regulation at all.

Sometimes regulation would violate the precautionary principle because it would give rise to substitute risks, in the form of hazards that materialize, or are increased, as a

\footnotetext{
${ }^{81}$ See Henry Grabowski and John Vernon, The Regulation of Pharmaceuticals (1983); John Mendeloff, Decision Analysis and FDA Drug Review: A Proposal for "Shadow" Advisory Committees (2002), available at http://www.fplc.edu/RISK/vol6/summer/mendelof.htm.

${ }^{82}$ See sources cited in note 64 supra.

${ }^{83}$ Bill Lambrecht, Dinner at the New Gene Cafe : How Genetic Engineering Is Changing What We Eat, How We Live, and the Global Politics of Food (2001) (tracing but not endorsing the various objections).

${ }^{84} \mathrm{Id}$.

${ }^{85}$ See American Trucking Association v. EPA, F.3d (DC Cir 2002).

${ }^{86}$ American Trucking Association v. EPA, 173 F.3d 1027, 1052 (DC Cir 1999).
} 
result of regulation. ${ }^{87}$ Consider the case of nuclear power. It is reasonable to think that in light of current options, a ban on nuclear power will increase dependence on fossil fuels, ${ }^{88}$ which contribute to global warming. If so, such a ban would seem to run afoul of the precautionary principle. Or consider the EPA's effort to ban asbestos, ${ }^{89}$ a ban that might well seem justified or even compelled by the precautionary principle. The difficulty, from the standpoint of that very principle, is that substitutes for asbestos also carry risks. ${ }^{90}$ Or return to possible risks to marine mammals from the United States Navy. Some people are concerned that efforts to eliminate those risks will endanger military preparedness, if only because of administrative barriers to training exercises. ${ }^{91}$ In these circumstances, what is the appropriate approach, according to the precautionary principle?

The problem is pervasive. In the case of arsenic, the Administrator of the EPA has expressed concern that regulation, by virtue of its cost, will lead people to cease using local water systems and to rely on private wells, which have high levels of contamination. ${ }^{92}$ If this is so, stringent arsenic regulation violates the precautionary principle, no less than less stringent regulation does. This is a common situation, for opportunity benefits and substitute risks are the rule, not the exception. ${ }^{93}$

\footnotetext{
${ }^{87}$ See the discussion of risk-related tradeoffs in John Graham and Jonathan Wiener, Risk vs. Risk (1985); Cass R. Sunstein, Health-Health Tradeoffs, in Cass R. Sunstein, Risk and Reason (forthcoming 2002).

${ }^{88}$ See Breyer, supra note.

${ }^{89}$ See Corrosion Proof Fittings v. EPA, 947 F.2d 1201 (5 $5^{\text {th }}$ Cir. 1991).

${ }^{90}$ Id. at

${ }^{91}$ See Testimony of Vice Admiral Charles W. Moore, supra note.

92 "But we have seen instances, particularly in the West and Midwest, where arsenic is naturally occurring at up to 700 and more parts per billion, where the cost of remediation has forced water companies to close, leaving people with no way to get their water, save dig wells. And then they are getting water that's even worse than what they were getting through the water company." Interview by Robert Novak \& Al Hunt, CNN Evans, Novak, Hunt \& Shields, Cable News Network, with Christine Todd Whitman, Administrator, U.S. Environmental Protection Agency (Apr. 21, 2001).

${ }^{93}$ Consider the treatment of DDT in Goklany, supra note, at 13-27, and in particular the emphasis on the public health risks of banning DDT, in the form of increasing malaria risks, in id. at 15-18. Note also that some regulation will have ancillary benefits, by reducing risks other than those that are specifically targeted. For a valuable discussion, see Richard Revesz, U. Chi. L. Rev. (forthcoming 2002).
} 
It is possible to go much further. A great deal of evidence suggests the possibility that an expensive regulation can have adverse effects on life and health. ${ }^{94}$ To be sure, both the phenomenon and the underlying mechanisms are disputed. ${ }^{95}$ It has been urged that a statistical life can be lost for every expenditure of $\$ 7$ million $^{96}$; it has also been estimated that the requisite expenditure, for a loss of life, is $\$ 50$ million $^{97}$; and one of the most careful studies suggests a cutoff point, for a loss of life per regulatory expenditure, of $\$ 15$ million. ${ }^{98}$ A striking study suggests that poor people are especially vulnerable to this effect - that a regulation that reduces wealth for the poorest $20 \%$ of the population will have twice as large a mortality effect as a regulation that reduces wealth for the wealthiest $20 \%{ }^{99}$ I do not mean to accept any particular amount here, or even to suggest that there has been an unambiguous demonstration of an association between mortality and regulatory expenditures. ${ }^{100}$ The only point is that reasonable people believe in that association. It follow that a multimillion dollar expenditure for "precaution" has - as a worst case scenario - significant adverse health effects, with an expenditure of $\$ 200$ million as leading to perhaps as many as thirty to forty lives lost.

This point makes the precautionary principle hard to implement not merely where regulation removes "opportunity benefits," or introduces or increases substitute risks, but also in any case in which the regulation costs a significant amount. If this is so, the precautionary principle, for that very reason, seems to argue against many regulations. If the precautionary principle argues against any action that carries a small risk of significant harm, then we should be reluctant to spend a lot of money to reduce risks,

\footnotetext{
${ }^{94}$ Ralph Kenney, Mortality Risks of Induced by the Costs of Regulation, 10 Risk Analysis 147 (1990); Randall Lutter \& John F. Morrall, III, Health-Health Analysis: A New Way to Evaluate Health and Safety Regulation, 8 J Risk \& Uncertainty 43, 49 table 1 (1994).

${ }^{95}$ See Randall Lutter \& John F. Morrall, III, Health-Health Analysis: A New Way to Evaluate Health and Safety Regulation, 8 J Risk \& Uncertainty 43, 49 table 1 (1994).

${ }^{96}$ See Keeney, supra note.

${ }^{97}$ See W. Kip Viscusi and Richard Zeckhauser, The Fatality and Injury Costs of Expenditures, 8 J Risk and Uncertainty 19 (1994).

${ }^{98}$ See Robert Hahn et al., Do Federal Regulations Reduce Mortality (Washington, DC: American Enterprise Institute, 2000).

${ }^{99}$ See Kenneth Chapman and Govind Hariharan, Do Poor People Have a Stronger Relationship Between Income and Mortality Than the Rich? Implications of Panel Data for Health-Health Analysis, 12 J Risk \& Uncertainty 51, 58-63 (1996).

${ }^{100}$ Paul R. Portney \& Robert N. Stavins, Regulatory Review of Environmental Policy: The Potential Role of Health-Health Analysis, 8 J Risk \& Uncertainty 111, 118 (1994) (arguing that adverse health effects from the cost of regulation are possible but unlikely).
} 
simply because those expenditures themselves carry risks. Here is the sense in which, the precautionary principle, taken for all that it is worth, is paralyzing: It stands as an obstacle to regulation and nonregulation, and to everything in between. To say this is not to say that the precautionary principle cannot be amended in a way that removes the problem. ${ }^{101}$ But once it is so amended, it is much less distinctive, and increasingly resembles an effort to weight the health benefits or regulation against the health costs, ${ }^{102}$ or even to measure benefits against costs. I will return to this point below.

It is now easier to understand the earlier suggestion that despite its formal enthusiasm for the precautionary principle, European nations are not "more precautionary" than the United States. Jonathan Wiener and Michael Rogers have demonstrated this point empirically. ${ }^{103}$ It would be most valuable to attempt to comparative study, to see which nations are especially precautionary with respect to which risks, and also to explore changes over time. In the early twenty-first century, for example, the United States appears to take a highly precautionary approach to the risks associated with abandoned hazardous waste dumps, ${ }^{104}$ terrorism, and the provision of universal health care, but not to take a highly precautionary approach to the risks associated with global warming, ${ }^{105}$ indoor air pollution, poverty, poor diet, and obesity. What I have been urging is that the selectivity of precautions is not merely an empirical fact; it is a conceptual inevitability. Simply as a logical matter, no society can be highly precautionary with respect to all risks.

\section{B. Rejoinders, Adjustments, and Salutary Goals}

Is there anything that might be said, at this stage, by proponents of the precautionary principle? There are several possibilities.

\footnotetext{
${ }^{101}$ For various efforts, see Goklany, supra note, at 89-94; Wiener, supra note.

${ }^{102}$ See John Graham and Jonathan Wiener, Risk vs. Risk (1995).

${ }^{103}$ See Wiener and Rogers, supra note.

104 See W. Kip Viscusi and James Hamilton, Calculating Risks (2000).

${ }^{105}$ For the current responses, see http://www.whitehouse.gov/news/releases/2002/02/climatechange.html
} 
1. The weak version. It might be tempting to revert to the weak version of the principle - a version that is entirely unobjectionable. Alternatively, it might be urged that in many cases in which the principle is invoked, the risk at issue is the one that deserves the most sustained attention. In the context of global warming, for example, the precautionary principle might be triggered on the ground that the potential risks of warming are far greater than the risks associated with the reduction of greenhouse gases. But this step points toward a sensible and substantial refashioning of the principle, one that ensures that low-probability catastrophes are given careful attention, and that the various risks at issue will be weighed and balanced in accordance with the facts.

2.. Biases. In addition, advocates of the precautionary principle might urge that environmental values are systematically disregarded in the regulatory process, or not given their due, and hence that the principle helps counteract systematic biases. ${ }^{106} \mathrm{~A}$ particular problem here is myopia ${ }^{107}$ : Perhaps government officials, uninformed by the precautionary principle, would fail to attend to risks that will not occur, or be seen to occur, in the short-run. Another problem is that people tend to be unrealistically optimistic. ${ }^{108}$ As a result, many low-level risks do not register at all. A related problem is that people tend to reduce cognitive dissonance, sometimes by treating risks as if they are tiny, even worth ignoring. ${ }^{109}$ When people think that they are "safe," even though they face a statistical risk, they might well be responding to emotions, seeking to avoid the anxiety that comes from an understanding of the inevitability of risk.

On this view, the principle can be defended pragmatically, if not theoretically, as a way of emphasizing the importance of attending to issues, especially environmental issues, that might otherwise be neglected. In some settings, the pragmatic defense is undoubtedly plausible, and the precautionary principle, applied with a narrow viewscreen, undoubtedly leads to some good results. But two problems remain. The first

\footnotetext{
${ }^{106}$ See Richard B. Stewart, Regulation in a Liberal State: The Role of Noncommodity Values, 92 Yale LJ 1537 (1983).

${ }^{107}$ See the treatment of hyberbolic discounting in Richard Thaler, Quasi-Rational Economics (1995).

${ }^{108}$ See Shelley Taylor, Positive Illusions 9-12 (1989).

${ }^{109}$ See George Akerlof and William Dickens, The Economic Consequences of Cognitive Dissonance, in George Akerlof, An Economic Theorist's Book of Tales 123, 124-28 (1984).
} 
is that environmental values are sometimes on both sides of the controversy; consider the nuclear power controversy. The same is certainly true of health and safety, as shown by the case of premarket testing of pharmaceuticals. The second is that even when environmental values are on only one side, the interests and values on the other side might well be at a comparative disadvantage too; consider the potential beneficiaries of genetic modification of food. In short, a more modest and revised precautionary principle might well make sense, but the less modest, and more distinctive, principle is hard to defend.

3. Distribution. It is also possible to defend the precautionary principle on distributional grounds. The Clean Air Act takes a precautionary approach, requiring an "adequate margin of safety" and hence regulation in the fact of scientific uncertainty. ${ }^{110}$ At the same time, the Clean Air Act appears to be giving disproportionate benefits to poor people and members of minority groups. ${ }^{111}$ Aggressive action to combat climate change would be more beneficial to poor countries than to wealthy ones. ${ }^{112}$ This is partly because wealthy countries are better able to adapt; it is partly because agriculture, potentially vulnerable to climate change, is responsible for only $2 \%$ of the economy of wealthy nations, but $50 \%$ of the economy of poor nations ${ }^{113}$; it is partly because one of the most serious health risks posed by climate change consists of an increased incidence of malaria, a nonproblem for wealthy countries. ${ }^{114}$ In the context of global warming, at least, the precautionary principle might be invoked to prevent especially severe burdens on those in the worst position to bear them.

Of course it makes sense to be concerned with the distribution of domestic or international risks. The problem of global warming owes its origin to the actions of wealthy nations, and hence it makes special sense to ask those nations to bear a disproportionate cost of correction if poor nations are likely to be hit hardest. The

\footnotetext{
${ }^{110}$ See 42 USC 7409(b(1); American Trucking Associations v. EPA, F.3d (March 26, 2002).

${ }^{111}$ See Matthew E. Kahn, The Beneficiaries of Clean Air Act Regulation, 24 Regulation 34 (2001).

${ }^{112}$ See, e.g., Joseph Aldy, Peter Orszag, and Joseph Stiglitz, Climate Change: An Agenda for Gloval Collective Action (unpublished manuscript 2001); Lomborg, supra note, at 291-302.

${ }^{113}$ See id.

${ }^{114}$ See sources cited in note 87 supra.
} 
distributional effects of global warming are among the strongest points in favor aggressive regulation of greenhouse gases. ${ }^{115}$ But in many cases, the precautionary principle, as applied, would threaten to have unfortunate distributional effects. The case of genetic modification of food is an example; here the benefits are likely to be enjoyed by poor people, not the wealthy. ${ }^{116}$ The case of DDT is similar. While a ban on DDT, supported by reference to the precautionary principle, is eminently justified in wealthy nations, such a ban is likely to have bad effects in at least some poor countries, where DDT is the cheapest and most effective way of combating serious diseases, most notably malaria. ${ }^{117}$ Distributional issues should indeed be a part of a system of risk regulation, but the precautionary principle is a crude, indirect, and sometimes perverse way of incorporating distributional concerns.

4. Risk vs. uncertainty. A more subtle point is possible. Often regulators, and ordinary people, are acting in a situation of risk (where probabilities can be assigned to various outcomes) rather than uncertainty (where no such probabilities can be assigned). ${ }^{118}$ Thus far I have been speaking as if environmental and other risk-related problems involved a risks of ascertainable probability — so that analysts are able to say that the risk of $\mathrm{X}$ number of deaths in $\mathrm{Y}$ percent, whereas the risk of $2 \mathrm{X}$ number of deaths is $\mathrm{Y} / \mathrm{n}$, and so forth. But we can imagine instances in which analysts cannot specify even a range of probability, and in which the extent of the harm is also not susceptible to even vague probabilistic prediction. ${ }^{119}$

In a situation of uncertainty, when existing knowledge does not permit regulators to assign probabilities to outcomes, it is standard to follow the maximin principle: Choose the policy with the best worst-case outcome. ${ }^{120}$ Perhaps the precautionary principle, as

\footnotetext{
${ }^{115}$ Note, however, that if the concern involves poor countries, it is not clear that global warming is an especially high priority, in light of the many needs of those countries, needs that might be addressed by wealthier nations. See Lomborg, supra note, at 322-23; Goklany, supra note, at 71-88.

${ }^{116}$ See Goklany, supra, at 55.

${ }^{117}$ Cass R. Sunstein, Risk and Reason (forthcoming 2002); Aaron Wildavsky, But Is It True? 61 (1995).

${ }^{118}$ Sere Frank H. Knight, Risk, Uncertainty, and Profit (1933); Paul Davidson, Is Probability Theory Relevant for Uncertainty? A Post-Keynesian Perspective, 13 Journal of Post-Keynesian Economics 129 (1991).

${ }^{119}$ See Stewart, supra note, at 73-74, 90-92.

${ }^{120}$ See Jon Elster, Explaining Technical Change 185-207 (1983), for a helpful discussion.
} 
applied, is a form of the maximin principle, asking officials to identify the worst case among the various options, and to select that option whose worst-case is least bad. Perhaps the maximin principle would support many proposed applications of the precautionary principle, by, for example, urging aggressive steps to combat global warming.

This is not an implausible suggestion; sometimes it is best to respond to the worstcase scenario, as some governments do in the face of risks to national security (not excluding those risks posed by terrorism). But the response faces three problems. The first is that the precautionary principle is not the maximin principle, and if the latter principle is what is meant, then we should be discussing that principle directly, and evaluating it against the alternatives. The precautionary principle obscures those issues. The second problem is that so defended, the principle might well prevent rational priority-setting, simply because it "leads to a disproportionate allocation of limited regulatory priorities to those activities posing relatively more uncertainty, because the worst case assumption inflates their harm value relative to risks that are better characterized." ${ }^{121}$ The third problem is that risks that are now in the realm of uncertainty will often move, over time, into the realm of risk. Indeed, one of the principal goals of a well-functioning system of environmental protection is to acquire more information about potential hazards, information that includes an understanding of the probability of harm. In some circumstances, acquiring information is far better than responding to the worstcase scenario, at least when that response itself creates dangers in the realm of both uncertainty and risk. ${ }^{122}$

5. Salutary goals. We are now in a position to appreciate some of the goals of those who invoke the precautionary principle. Serious environmental problems might be addressed too late, or not at all, simply because causal connections cannot be described with certainty. In the context of tobacco, for example, a serious public health movement

\footnotetext{
${ }^{121}$ Stewart, supra note, at 97.

122 See id. at 106-112.
} 
was muted simply by virtue of scientific doubt ${ }^{123}$ _ even though reasonable people take steps to reduce likelihoods, not only certainties, of adverse effects. The precautionary principle can be taken as a reminder not to require proof. To the extent that the precautionary principle is a reminder of obligations to the future, it is entirely salutary. Those who invoke the principle undoubtedly are motivated, much of the time, by the goal of protecting the most vulnerable people against risks to their safety and health. ${ }^{124}$ On this view, the precautionary principle has strong moral goals, and they are distributive in character.

Nothing I have said is meant to draw these goals into doubt. My claim is that the precautionary principle is a crude and sometimes perverse way of promoting the relevant goals - and that if it is taken seriously, it is paralyzing, and therefore not helpful at all.

\section{The Operation of the Precautionary Principle: A Behavioral Account}

In practice, the precautionary principle is widely thought to provide concrete guidance. ${ }^{125}$ How can this be? I suggest that the principle becomes operational if and only if those who apply it wear blinders - only, that is, if they focus on some aspects of the regulatory situation but downplay or disregard others. Consider, for example, those who think that the precautionary principle requires restrictions on genetic engineering of food; to have this belief, it is necessary to ignore the potential health benefits of the practice. Or consider those who think that the precautionary principle calls for stringent regulation of greenhouse gases; such people neglect the need to adopt precautions against the very risks introduced by stringent regulation. In the same vein, those who invoke the precautionary principle to seek regulation of human cloning neglect the possibility that without therapeutic cloning, many people will die. ${ }^{126}$

\footnotetext{
${ }^{123}$ See Robert Goodin, No Smoking (1985).

124 See note 1 supra.

125 See, e.g., Implementing the Precautionary Principle, supra note.

${ }^{126}$ See Testimony of Dr. Brent Blackwelder, supra note.
} 
But these points simply raise an additional question: Why is the precautionary principle so influential? Why does it speak to so many people? I believe that much of the answer lies in an understanding of behavioral economics and cognitive psychology. Five points are especially pertinent. Taken together, they help explain the kinds of blinders that people wear when they use the precautionary principle to support concrete outcomes. The points help show the sense in which the relevant blinders are not arbitrary or coincidental. They have some unmistakable structure.

\section{A. Loss Aversion and Familiarity}

1. In general. People tend to be loss averse, which means that a loss from the status quo is seen as more undesirable than a gain is seen as desirable. ${ }^{127}$ To see how loss aversion works, consider some of the classic experiments, which involve the endowment effect. ${ }^{128}$ People who were initially endowed with certain goods-such as coffee mugs, chocolate bars, and binoculars - valued those goods far more than those who were not initially endowed with them. The reason for the endowment effect is loss aversion ${ }^{129}$ : People are much more distressed by the prospect of loss than they are pleased by the prospect of equivalent gain. Another way to put the point is to say that contrary to economic theory, people do not value out-of-pocket costs and opportunity costs the same. Opportunity costs, as foregone gains, seem to be far less bad, on a per-dollar basis, than out-of-pocket costs.

In the context of risk regulation, there is a clear implication: People will be closely attuned to the losses produced by any newly introduced risk, or any aggravation of existing risks, but far less concerned with the benefits that are foregone as a result of

\footnotetext{
${ }^{127}$ See Richard H. Thaler, The Psychology of Choice and the Assumptions of Economics, in Quasi Rational Economics 137, 143, Richard H. Thaler ed. (New York: Russell Sage Foundation, 1991) (arguing that "losses loom larger than gains"); Daniel Kahneman, Jack L. Knetsch, \& Richard H. Thaler, Experimental Tests of the Endowment Effect and the Coase Theorem, 98 J. Pol. Econ. 1325, 1328 (1990); Colin Camerer, Individual Decision Making, in The Handbook of Experimental Economics 665-670, John H. Kagel \& Alvin E. Roth, eds. (1995).

${ }^{128}$ See Richard Thaler, Quasi-Rational Economics (1993).

${ }^{129}$ Of course loss aversion itself remains to be explained. For relevant discussion, see Cass R. Sunstein, Switching the Default Rule, NYU L Rev (forthcoming 2002).
} 
regulation. I believe that loss aversion helps to explain what makes the precautionary principle operational: The opportunity costs of regulation often register little or not at all, whereas the out-of-pocket costs of the activity or substance in question are entirely visible. In fact this is a form of status quo bias. ${ }^{130}$ The status quo marks the baseline against which gains and losses are measured, and a loss from the status quo seems much more bad than a gain from the status quo seems good.

If loss aversion is at work, we would predict that the precautionary principle would place a spotlight on the losses introduced by some risk, and downplay the benefits foregone as a result of controls. In fact this is what we have observed in several contexts. ${ }^{131}$ Whenever the "opportunity benefits" are off-screen, this will be the reason that the precautionary principle appears to give guidance notwithstanding the objections I have made. At the same time, the neglected opportunity benefits present a devastating problem with the use of the precautionary principle. In the context of genetic engineering of food, this is very much the situation. ${ }^{132}$ We can find the same problem when the precautionary principle is invoked to support bans on nonreproductive cloning. ${ }^{133}$ For many people, the possible harms of cloning register more strongly than the potential therapeutic benefits that would eliminated by a ban on the practice.

Loss aversion is closely associated with another cognitive finding: People are far more willing to tolerate familiar risks than unfamiliar ones, even if they are statistically equivalent. ${ }^{134}$ The risks associated with driving do not occasion a great deal of concern, even though tens of thousands of people die from motor vehicle accidents each year. The relevant risks are simply seen as part of life. By contrast, many people are quite concerned about risks that appear newer, such as the risks associated with genetically modified foods, newly introduced chemicals, nuclear power plants, and terrorism. Part of the reason for the asymmetry may be a belief that with new risks, we are in the domain of

\footnotetext{
${ }^{130}$ See Samuelson and Zeckhauser, Status Quo Bias, J. Risk \& Uncertainty.

${ }^{131}$ See above.

${ }^{132}$ See Katherine Barrett and Gabriela Flora, Genetic Engineering and the Precautionary Principle (2000), available at http://www.npsas.org/GEPrecautionary.html

${ }^{133}$ See Testimony of Dr. Brent Blackwelder, supra note.

${ }^{134}$ See Paul Slovic, The Perception of Risk 140-143 (2000).
} 
uncertainty rather than risk, and hence it makes sense to be cautious when probabilities cannot be assigned. But the individual and social propensity to focus on new risks outruns that sensible propensity; it makes the precautionary principle operational by emphasizing a subset of the hazards actually involved.

\section{B. The Mythical Benevolence of Nature}

Sometimes the precautionary principle operates by incorporating the belief that nature is essentially benign and that human intervention is likely to carry risks - as in the suggestion that the precautionary principle calls for stringent regulation of pesticides. This is a distinctive form of loss aversion. The idea is that any human intervention will create loss from the status quo, and that this loss should carry great weight, whereas the gains should be regarded with some suspicion or at least be taken as less weighty. Often lose aversion and a belief in nature's benevolence march hand-in-hand: The status quo forms the baseline or reference state against which to assess deviations. Processes that interfere with nature seem, on the part of many, to be taken as troubling "degradation"whereas gains or improvements seem, other things being equal, far less significant.

A belief in the benevolence of nature does seem to play a role in the operation of the precautionary principle, especially among those who see nature as harmonious or in balance. In fact many of those who endorse the principle seem to be especially concerned about new technologies. Certainly most people believe that natural chemicals are more safe than man-made chemicals. ${ }^{135}$ (Most toxicologists disagree. ${ }^{136}$ ) On this view, the principle calls for caution when people are intervening into the natural world. Here of course we can find considerable sense: Nature often consists of systems, and interventions into systems can cause a number of problems. New technologies can produce unintended bad effects, if only because they interfere with systems. But there is a

\footnotetext{
${ }^{135}$ See Paul Slovic, The Perception of Risk 291 (2000).

${ }^{136} \mathrm{See}$ id.
} 
large problem with this understanding of the precautionary principle. What is natural may not be safe at all. ${ }^{137}$

Consider, for example, the idea that there is a "balance of nature." According to a recent account, this idea is "not true." "138 A scientific "revolution has shown that nature "is characterized by change, not constancy," 139 and that "natural ecological systems are dynamic," with desirable changes being "those induced through human action." case nature is often a realm of destruction, illness, killing, and death. ${ }^{141}$ Hence the claim cannot be that human activity is necessarily or systematically more destructive than what nature does. Nor is it clear that natural products are comparatively safe. ${ }^{142}$ Organic foods, favored by many people on grounds of safety and health and creating annual revenues of $\$ 4.5$ billion in the United States alone, are "actually riskier to consume than food grown with synthetic chemicals." 143 If the precautionary principle is seen to raise doubts about pesticides, but not about organic foods, it is probably because the health risks that come with departures from "nature" register as especially troublesome. Of course some of the most serious risks are a product of nature. Tobacco smoking kills 400,000 Americans each year; the precautionary principle might be (but has not been) directed against it. Nothing is more natural than exposure to sunlight, but such exposure is associated with skin cancer and other harms, ${ }^{144}$ producing serious health problems that have not been the occasion for invoking the precautionary principle.

To say this is not to resolve specific issues, which depend on complex questions of value and fact. ${ }^{145}$ My only suggestion is that the false belief in a benevolence of nature

\footnotetext{
${ }^{137}$ See James P. Collman, Naturally Dangerous (2001).

${ }^{138}$ See Botkin, Adjusting Law to Nature's Discordant Harmonies, 7 Duke Env'1 Law and Policy Forum 25, 27 (1996).

139 Id.

${ }^{140}$ Id. at 33.

${ }^{141}$ As elaborated in detail in John Stuart Mill, Nature, in Three Essays on Religion 3, 28-31 (1996).

142 See Collman, supra note.

${ }^{143}$ Id. at 31 .

${ }^{144}$ Id. at 199-201.

${ }^{145}$ For a helpful discussion of genetic modification of food and related issues, see McHughen, Pandora's Picket Basket, supra note.
} 
help to explain why the precautionary principle is thought, quite incorrectly, to provide a great deal of analytical help.

\section{The Availability Heuristic}

It is well-established that in thinking about risks, people rely on certain heuristics, or rules of thumb, which serve to simply their inquiry. ${ }^{146}$ Of these rules of thumb, the availability heuristic is most important for purposes of understanding the law relating to risks. ${ }^{147}$ The availability heuristic also helps illuminate the operation of the precautionary principle, by showing why some hazards will be on-screen and why others will be neglected. For example, "a class whose instances are easily retrieved will appear more numerous than a class of equal frequency whose instances are less retrievable." Tversky and Kahneman demonstrate the point with a simple study showing people a list of well-known people of both sexes, and asking them whether the list contains more names of women or more names of men. In lists in which the men were especially famous, people thought that the list had more names of men, whereas in lists in which the women were the more famous, people thought that the list had more names of women. ${ }^{149}$

This is a point about how familiarity can affect the availability of instances. A risk that is familiar, like the risk associated with nuclear power, will be seen as more serious than a risk that is less familiar, like the risk associated with heat during the summer. ${ }^{150}$ But salience is important as well. "For example, the impact of seeing a house burning on the subjective probability of such accidents is probably greater than the impact of reading about a fire in the local paper." 151 So too, recent events will have a greater impact than earlier ones. The point helps explain much risk-related behavior, including decisions to take precautions. For example, whether people will buy insurance for natural disasters is

\footnotetext{
${ }^{146}$ See Daniel Kahneman, Paul Slovic, and Amos Tversky, Judgment Under Uncertainty: Heuristics and Biases (1982).

${ }^{147}$ See Amos Tversky and Daniel Kahneman, Judgment Under Uncertainty: Heuristics and Biases, in id. at $3,11-14$.

${ }^{148}$ Id. at1 1.

${ }^{149} \mathrm{Id}$

${ }^{150}$ See Eric Klinenberg, supra note.

${ }^{151} \mathrm{Id}$.
} 
greatly affected by recent experiences. ${ }^{152}$ If floods have not occurred in the immediate past, people who live on flood plains are far less likely to purchase insurance. ${ }^{153}$ In the aftermath of an earthquake, insurance for earthquakes rises sharply_but it declines steadily from that point, as vivid memories recede. ${ }^{154}$ Note that the use of the availability heuristic, in these contexts, is hardly irrational. ${ }^{155}$ Both insurance and precautionary measures can be expensive, and what has happened before seems, much of the time, to be the best available guide to what will happen again. The problem is that the availability heuristic can lead to serious errors, in terms of both excessive fear and neglect.

The availability heuristic helps to explains the operation of the precautionary principle for a simple reason: Sometimes a certain risk, said to call for precautions, is cognitively available, whereas other risks, including the risks associated with regulation itself, are not. For example, it is easy to see that arsenic is potentially dangerous; arsenic is well-known as a poison, forming the first word of a well-known movie about poisoning. ${ }^{156}$ By contrast, there is a relatively complex mental operation in the judgment that arsenic regulation might lead people to use less safe alternatives. In many cases where the precautionary principle seems to offer guidance, the reason is that some of the relevant risks are available while others are barely visible.

It is well-known that the availability heuristic affects risk judgments, and we can now appreciate the relationship between that heuristic and the operation of the precautionary principle. But to say the least, the availability heuristic does not operate in

\footnotetext{
${ }^{152}$ Paul Slovic, The Perception of Risk 40 (2000).

${ }^{153} \mathrm{Id}$.

${ }^{154} \mathrm{Id}$.

${ }^{155}$ Kahneman and Tversky emphasize that the heuristics they identify "are highly economical and usually effective," but also that they "lead to systematic and predictable errors." See Amos Tversky and Daniel Kahneman, Judgment Under Uncertainty: Heuristics and Biases, in Judgment and Decision Making: A Interdisciplinary Reader 38, 55 (Hal Arkes and Kenneth Hammond). Gerd Gigenzer, among others, has emphasized that some heuristics can work extremely well, see Gerd Gigerenzer et al., Simple Heuristics That Make Us Smart (1999); Gerd Gigerenzer, Adaptive Thinking: Rationality in the Real World (2000), and used this point as a rejoinder to those who stress the errors introduced by heuristics and biases. For a helpful recent discussion, see Kahneman and Frederick, supra note. I do not mean to take a stand on the resulting debates. Even if many heuristics mostly work well in daily life, a sensible government can do much better than to rely on them.

${ }^{156}$ Arsenic and Old Lace.
} 
a social vacuum. ${ }^{157}$ What is readily "available" to some individuals, groups, cultures, and even nations will not be available to all. In part because of the use of the availability heuristic, the precautionary principle does not call for bans on nuclear power plants in France, which has not caused serious health risks in that nation despite its heavy reliance on nuclear energy. ${ }^{158}$ By contrast, the Three Mile Island incident provoked intense concerns about nuclear power plants in the United States ${ }^{159}$ and helped promote the widespread idea that a precautionary approach would discourage reliance on nuclear power. Many of those who favor gun control legislation have "available" a set of incidents in which such legislation would have avoided unnecessary deaths; many of those who reject such legislation are alert to incidents in which private gun ownership allowed people to fend off criminal violence. ${ }^{160}$ Much remains to be done to clarify the relationship between the availability heuristic and social interactions, including the operations of the media and political officials. For present purposes, the key point is that the availability heuristic often underwrites the use of the precautionary principle, by suggesting the importance of taking precautions against some, but hardly all, of the risks involved.

\section{Probability Neglect}

The availability heuristic can produce an inaccurate assessment of probability. But sometimes people will attempt little assessment of probability at all, especially when strong emotions are involved. ${ }^{161}$ In such cases, large-scale variations in probabilities will matter little-even when those variations unquestionably should matter. The point applies to hope as well as fear; vivid images of good outcomes will crowd out consideration of probability too. ${ }^{162}$ Lotteries are successful partly for this reason. ${ }^{163}$ But

${ }^{157}$ See Dan Kahan and Donald Braman, More Statistics, Less Persuasion: A Cultural Theory of Risk Perception (unpublished manuscript 2002); Timur Kuran and Cass R. Sunstein, Availability Cascades and Risk Regulation, 51 Stan L Rev 683 (1999).

${ }^{158}$ See Kuran and Sunstein, supra note.

${ }^{159}$ See id.

${ }^{160}$ See Kahan and Braman, supra note.

${ }^{161}$ Yuval Rottenstreich and Christopher Hsee, Money, Kisses, and Electric Shocks: On the Affective Psychology of Probability Weighting, supra, at 176-88.

${ }_{162}^{162}$ See id.

${ }^{163}$ See Phillip Cook, Selling Hope (1993). 
for purposes of applying the precautionary principle, the topic is fear rather than hope. I suggest that sometimes the precautionary principle becomes workable because the issue of probability is neglected, and people focus on one emotionally gripping outcome among a large set of possibilities.

Probability neglect has received its clearest empirical confirmation in a striking study of people's willingness to pay to avoid electric shocks. ${ }^{164}$ The central purpose of the study was to test the relevance of probability in "affect rich" decisions. One experiment investigated whether varying the probability of harm would matter more, or less, in settings that trigger strong emotions than in settings that seem relatively emotionfree. In the "strong emotion" setting, participants were asked to imagine that they would participate in an experiment involving some chance of a "short, painful, but not dangerous electric shock." ${ }^{, 165}$ In the relatively emotion-free setting, participants were told that the experiment entailed some chance of a $\$ 20$ penalty. Participants were asked to say how much they would be willing to pay to avoid participating in the relevant experiment. Some participants were told that there was a $1 \%$ chance of receiving the bad outcome (either the \$20 loss or the electric shock); others were told that the chance was 99\%; and still others were told that the chance was $100 \%$.

The central result was that variations in probability affected those facing the relatively emotion-free injury, the $\$ 20$ penalty, far more than they affected people facing the more emotionally evocative outcome of an electric shock. ${ }^{166}$ For the cash penalty, the difference between the median payment for a $1 \%$ chance and the median payment for a $99 \%$ chance was predictably large and indeed consistent with the standard model: $\$ 1$ to avoid a $1 \%$ chance, and $\$ 18$ to avoid a $99 \%$ chance ${ }^{167}$ For the electric shock, by contrast, the difference in probability made little difference to median willingness to pay: $\$ 7$ to avoid a $1 \%$ chance, and $\$ 10$ to avoid a $99 \%$ chance! ${ }^{168}$ Apparently people will pay a

${ }^{164}$ Yuval Rottenstreich and Christopher Hsee, Money, Kisses, and Electric Shocks: On the Affective Psychology of Probability Weighting, supra, at 176-88.

${ }^{165}$ Id. at 181.

${ }^{166} \mathrm{Id}$.

${ }^{167} \mathrm{Id}$.

${ }^{168} \mathrm{Id}$. 
significant amount to avoid a small probability of a hazard that is affectively-laden — and the amount that they will pay will not vary greatly with changes in probability. The point explains "why societal concerns about hazards such as nuclear power and exposure to extremely small amounts of toxic chemicals fail to recede in response to information about the very small probabilities of the feared consequences from such hazards." ${ }^{169}$

It should be easy to the connection between probability neglect and the precautionary principle. If probabilities are neglected, especially when emotions are engaged, then the principle will operate through excessive public concern with certain low-probability hazards. Return to the contrast between deaths from heat waves and deaths from airplane crashes. ${ }^{170}$ The latter trigger far more intense public attention, in part because of the availability heuristic, but in part because for some people, the outcome itself has such salience, and the probability much less so. In the context of genetic modification of food and global warming, the same phenomenon is at work, leading people to think that the precautionary principle, simply applied, calls for aggressive regulatory controls. Note that I am not urging that such controls are a mistake; in the context of global warming, they seem to be warranted by the facts. My claim is only that the precautionary principle appears to give guidance in part because the issue of probability is neglected.

For purposes of understanding the operation of the precautionary principle, it is important to see that visualization or imagery matters a great deal to people's reactions to risks. ${ }^{171}$ When an image of a bad outcome is easily accessible, people will become greatly concerned about a risk, holding probability constant. ${ }^{172}$ Consider the fact that when people are asked how much they will pay for flight insurance for losses resulting from "terrorism," they will pay more than if they are asked how much they will pay for flight

\footnotetext{
${ }^{169}$ See Paul Slovic et al., The Affect Heuristic, forthcoming in Intuitive Judgment: Heuristics and Biases (Tom Gilovich et al. eds, forthcoming), unpublished manuscript at 11.

${ }^{170}$ See Eric Klinenberg, supra note.

${ }^{171}$ See Paul Slovic et al., Violence Risk Assessment and Risk Communication, 24 Law and Human Behavior 271 (2000).

${ }^{172}$ See Loewenstein et al., supra, at 275-76.
} 
insurance from all causes. ${ }^{173}$ The evident explanation for this peculiar result is that the word "terrorism" evokes vivid images of disaster, thus crowding out probability judgments. Note also that when people discuss a low-probability risk, their concern rises even if the discussion consists mostly of apparently trustworthy assurances that the likelihood of harm really is infinitesmal. ${ }^{174}$ The reason is that the discussion makes it easier to visualize the risk and hence to fear it.

Note that probability neglect does not involve the availability heuristic. That heuristic leads not to neglect probability, but to answer the question of probability by substituting a hard question (what is the statistical risk?) with an easy question (do salient examples readily come to mind?). ${ }^{175}$ My point here is not that visualization makes an event seem more probable (though this is also often true), but that visualization makes the issue of probability less relevant or even irrelevant. In theory, the distinction between use of the availability heuristic and probability neglect should not be obscure. In practice, of course, it will often be hard to know whether the availability heuristic or probability neglect is driving behavior.

The most sensible conclusion is that with respect to risks of injury of harm, vivid images and concrete pictures of disaster can "crowd out" other kinds of thoughts, including the crucial thought that the probability of disaster is really small. "If someone is predisposed to be worried, degrees of unlikeliness seem to provide no comfort, unless one can prove that harm is absolutely impossible, which itself is not possible." 176 Probability neglect, I suggest, often makes the precautionary principle seem sensible and workable. Indeed, the precautionary principle often embodies a form of probability neglect. When people focus on highly speculative risks associated with certain risks, it is often because of intense emotional reactions that make those risks, and not relevant others, stand out from the background. In many cases, probability neglect and loss

\footnotetext{
${ }^{173}$ See E.J. Johnson et al., Framing, Probability Distortions, and Insurance Decisions, 7 H. Risk and Uncertainty 35 (1993).

${ }^{174}$ See A.S. Alkahami and Paul Slovic, A Psychological Study of the Inverse Relationship Bteween Perceived Risk and Perceived Benefit, 14 Risk Analysis 1086, 1094-94 (1994).

175 See Amos Tversky and Daniel Kahneman, Availability: A Heuristic for Judging Frequency and Probability, 5 Cognitive Psychology 207 (1973).

${ }^{176}$ See Weingart, supra note 1 , at 362.
} 
aversion march hand-in-hand. Potential losses, from the status quo, often trigger intense emotions, as potential gains do not; and when the precautionary principle is operating, the low-probability losses have far more salience than they deserve. ${ }^{177}$

Nor is the problem of probability neglect foreign to law. In many contexts, law seems to be a response, in part, to fear of bad outcomes without close attention to the question of probability - along one dimension, the precautionary principle in action. ${ }^{178}$ The European Community's ban on meat products treated with hormones has raised large-scale issues about the role of public fear in risk regulation. ${ }^{179}$ The Appellate Body of the World Trade Organization ruled ${ }^{180}$ that the ban ran afoul of Article 5.1 of the Agreement on Sanitary and Phytosanitary Measures (SPS Agreement), ${ }^{181}$ which requires members of the WTO to justify all health and safety regulations by reference to scientific risk assessments. ${ }^{182}$ In this way, the Appellate Body rejected the EC's effort to defend itself in part by reference to consumer fears about the safety of beef treated with hormones. ${ }^{183}$ In this context, such fears were apparently real, but they neglected the issue of probability. ${ }^{184}$

\footnotetext{
${ }^{177}$ With respect to global warming, this is the suggestion in Goklany, supra note, at 58-88, and Lomborg, supra note.

${ }^{178}$ See Sunstein, Probability Neglect, supra note, at

${ }^{179}$ For an illuminating discussion, see Howard Chang, Risk Regulation, Public Concerns, and the Hormone Dispute: Nothing to Fear Except Fear Itself? (unpublished manuscript 2002).

${ }^{180}$ Report of the Appellate Body, EC Measures Concerning Meat and Meat Products (Hormones), WT/DS48/AB/R \& WT/DS48/AB/R, Jan. 16, 1998 (adopted Feb. 13, 1998), available in Westlaw, WTO-DEC file, 1998 WL 25520 [hereinafter Appellate Body].

${ }^{181}$ See id. at 9208 (citing Agreement on the Application of Sanitary and Phytosanitary Measures art. 5.1, Apr. 15, 1994, annex 1A-4 to Final Act Embodying the Results of the Uruguay Round of Multilateral Trade Negotiations, 33 I.L.M. 1125 (1994) [hereinafter SPS Agreement]).

${ }^{182}$ See SPS Agreement, supra note, art. 5.1 ("Members shall ensure that their sanitary or phytosanitary measures are based on an assessment, as appropriate to the circumstances, of the risks to human, animal or plant life or health, taking into account risk assessment techniques developed by the relevant international organizations.").

${ }^{183}$ See Michele D. Carter, Selling Science Under the SPS Agreement: Accommodating Consumer Preference in the Growth Hormones Controversy, 6 MINN. J. GLOBAL TRADE 625, 627 (1997).

${ }^{184}$ For discussion of the complex normative issues, see Chang, supra note.
} 


\section{E. System Neglect}

The fourth point is, in a way, the largest. My suggestion is that much of the time, and with respect to risks, people neglect the systemic effect of one-shot interventions. They tend to assume that a change in a social situation would alter the part at issue, but without altering other parts. System neglect, thus understood, includes the general phenomenon of tradeoff neglect, by which people fail to see the frequent need to way competing variables against one another. ${ }^{185}$ But tradeoff neglect is only part of what is involved here. When the precautionary principle gives guidance, and when it goes wrong, it is often because those who use it are falling victim to system neglect.

The clearest evidence comes from the German psychologist Dietrich Dorner, who has designed some fascinating experiments to see whether people can reduce social risks. ${ }^{186}$ Dorner's experiments are run via computer. Participants are asked to reduce risks faced by the inhabitants of some region of the world. The risks may involve pollution, poverty, poor medical care, inadequate fertilization of crops, sick cattle, insufficient water, or excessive hunting and fishing. Through the magic of the computer, many policy initiatives are available_-improved care of cattle, childhood immunization, drilling more wells). Participants are able to choose among them. Once particular initiatives are chosen, the computer projects, over short periods and then over decades, what is likely to happen in the region.

In these experiments, success is entirely possible. Some initiatives will actually make for effective and enduring improvements. But many of the participants - even the most educated and professional - produce calamities. They do so because they fixate on isolated problems and do not see the complex, system-wide effects of particular interventions. For example, they may appreciate the importance of increasing the number of cattle, but once they do that, they create a serious risk of overgrazing, and they fail to

\footnotetext{
185 See Howard Margolis, Dealing With Risk (1995).

${ }^{186}$ Dietrich Dorner, The Logic of Failure: Recognizing and Avoiding Error in Complex Situations (1996).
} 
anticipate that problem. ${ }^{187}$ They may understand full well the value of drilling more wells to provide water, but they do not anticipate the energy and environmental effects of the drilling, which then endangers the food supply. Only the rare participant is able to see a number of steps down the road - to understand the multiple effects of one-shot interventions into the system, and to assess a wide range of consequences from those interventions. The successful participants seem to take small, reversible steps, or to see the full set of effects at once, and thus to protect themselves against major blunders. When people are not successful, it is because they fail to see that risks are parts of systems. ${ }^{188}$

How would the precautionary principle operate if invoked in Dorner's experiments? It should be easy to see that while the weaker version might provide some assistance, the stronger versions offer no help at all. There are simply too many risks against which one might take precautions. Precautions cannot be taken against all risks, not for the important but less interesting reason that resources are limited, but simply because efforts to redress any set of risks might produce risks of their own. The real world of risk regulation offers many analogues. ${ }^{189}$ To the extent that the precautionary principle appears to offer guidance, it is often because adverse systemic effects, and the need to take precautions against them, are simply being neglected.

Howard Margolis has used a related point to explain why experts have different risk judgments from ordinary people, and he has done so in a particular effort to explain why and when ordinary people will think, "Better safe than sorry." 190 Margolis thus offers some cognitive foundations for the precautionary principle, without explicitly discussing the idea. Margolis' goal is to cast light on some apparent anomalies in ordinary thinking about risks: Why do people believe that small risks from pesticides should be regulated, if comparatively small risks from X-rays are quite tolerable? Why are people so concerned about the risks of nuclear power, when experts tend to believe

\footnotetext{
${ }^{187}$ Id. at 6-11.

${ }^{188}$ For some real world analogues to Dorner's experiments, see James Scott, Seeing Like A State (1999).

${ }^{189}$ See Wiener, supra note.

${ }^{190}$ See Margolis, supra note.
} 
that the risks are quite low-lower, in fact, than the risks from competing energy sources, such as coal-fired power plants, which produce relatively little public objection?

Margolis suggests that people are sometimes subject to a kind of optical illusion, in which they see the harms associated with some activity or process, but fail to see the benefits. If so, they will tend to think, "better safe they sorry."191 If not, they will see some "fungibility" between both harms and benefits, and engage in the kind of tradeoff analysis that is more typical for experts. ${ }^{192}$ Margolis offers a nice example to support this suggestion. ${ }^{193}$ The removal of asbestos from schools in New York City was initially quite popular, indeed demanded by parents, even though experts believed that the risks were statistically small. (As it happens, the risk of a child getting cancer from asbestos insulation was about $1 / 3$ the risk of being struck by lightning.) But when it emerged that the removal would cause schools to be closed for a period of weeks, and when the closing caused parents to become greatly inconvenienced, parental attitudes turned right around, and asbestos removal seemed like a really bad idea. When the costs of the removal came on-screen, parents thought much more like experts, and the risks of asbestos seemed well worth tolerating: Statistically small, and on balance worth incurring. The precautionary principle often operates because of the visibility of only one side of the ledger, so that people think that parents in advance of asbestos removal, seeing the possibility of hazard without confronting the problems introducing by reducing it.

For an especially vivid example, consider the apparent views of Americans in the late 1990s. About 63 percent of Americans agreed with the statement: "Protecting the environment is so important that requirements and standards cannot be too high and continuing environmental improvements must be made regardless of cost." ${ }^{\text {194 }}$ In the same general vein, 59 percent supported the Kyoto Treaty on global warming, with only 21 percent opposed. ${ }^{195}$ But in the same period, 52 percent of Americans said that they would

\footnotetext{
191 Id. at $75-81$.

192 Id. at $75-92$.

${ }^{193}$ Id. at $124-28$.

${ }^{194}$ See The Program on International Policy Attitudes, Americans on the Global Warming Treaty, available at http://www.pipa.org/OnlineReports/GlobalWarming/glob_warm treaty.html at Box 15.

195 Id.
} 
refuse to support the Kyoto Treaty on global warming if "it would cost an extra $\$ 50$ per month for an average American household. ${ }^{1196}$ In fact only 11 percent of Americans would support the Kyoto Treaty if the monthly expense were $\$ 100$ or more. ${ }^{197}$ How can we explain strong majority support for "environmental improvements . . regardless of cost" and strong majority rejection of environmental improvements when the cost if high? The answer lies in the fact that people are not, in fact, willing to spend an infinite amount for environmental improvements, and that when the costs are squarely placed "on screen," people begin to weigh both costs and benefits.

There are many other examples. People seem quite concerned about the risks associated with dioxin, a real candidate for use of the precautionary principle, but far less concerned about the statistically equivalent risks associated with aflatoxin, a carcinogen found in peanut butter. ${ }^{198}$ When aflatoxin does not trigger public concern, a large part of the reason is that the burdens of banning aflatoxin seem high and indeed intolerable; too many people would object to heavy regulation of peanut butter, a staple of school lunches and many diets for generations. In this light it is both mildly counterintuitive and reasonable, for example, to predict that people would be willing to pay less, in terms of dollars and waiting time, to reduce low-probability risks of an airplane disaster if they are frequent travellers. An intriguing study finds exactly that effect. ${ }^{199}$ It is also safe to predict that if people were told, by a reliable source, that eliminating pesticides would lead to serious health problems - for example, because pesticide-free fruits and vegetables carried special dangers ${ }^{200}$ - the perceived risk of pesticides would decline dramatically, and it would be difficult to invoke the precautionary principle as a basis for stringent regulation of pesticides. ${ }^{201}$ Indeed I predict that if people were informed that eliminating pesticides would lead to a significant cost in the price of applies and oranges, the perceived risk would go down as well. ${ }^{202}$

\footnotetext{
${ }^{196}$ Id. at Box 16.

${ }^{197} \mathrm{Id}$.

${ }^{198}$ Id. at 136-37.

${ }^{199}$ See Matthew Harrington (unpublished manuscript).

${ }^{200}$ See the discussion of organic food in McHughen, supra note, at 232-37.

${ }^{201}$ Carolyn Raffensperger, The Precautionary Principle as Forecaring: Hopeful Work for the Environmental Health Movement (2000), available at http://www.biotech-info.net/forecaring.html

${ }^{202}$ For evidence of the general phenomenon, see Paul Slovic, The Perception of Risk (2000).
} 
The conclusion is that the precautionary principle often seems helpful because analysts are focussing on the "target" risk, and not on the systemic, risk-related effects of being precautionary, or even on the risk-related consequences of risk reduction. Rational regulators, of course, think about systems, not snapshots. ${ }^{203}$ And once we see that risks are inevitably parts of systems, the precautionary principle will become far less helpful.

\section{Toward Wider Viewscreens}

In this Article I have argued not that the precautionary principle leads in the wrong directions, but that if it is taken for all that it is worth, it leads in no direction at all. The reason is that risks of one kind or another are on all sides of regulatory choices, and it is therefore impossible, in most real-world cases, to avoid running afoul of the principle. Frequently risk regulation creates a (speculative) risk from substitute risks or from foregone risk-reduction opportunities. And because of the (speculative) mortality and morbidity effects of costly regulation, any regulation, if it is costly, threatens to run afoul of the precautionary principle. We have seen that both regulation and nonregulation seem to be forbidden in cases involving nuclear power, arsenic, global warming, and genetic modification of food. The precautionary principle seems to offer guidance only because people blind themselves to certain aspects of the risk situation, focusing on a mere subset of the hazards that are at stake.

To some extent, those who endorse the precautionary principle seem to be responding to salutary political or moral motivations that the principle might be thought to embody. Well-organized private groups sometimes demand conclusive proof of harm

\footnotetext{
${ }^{203}$ There might seem to be some tension between the plea for wide viewscreens and my (qualified) argument for a form of judicial minimalism, in Cass R. Sunstein, One Case At A Time (1999). But there is no tension. Minimalism is a form of incrementalism, arguing on behalf of "small steps" in part because of the risk that large-scale interventions into systems will have unanticipated adverse consequences. See id. at 52-53. Indeed, Dorner himself suggests that small steps are a desirable approach to the risk of system neglect. See The Logic of Failure, supra, at 166-81. By endorsing a wide viewscreen, I do not mean to challenge small steps, but instead to urge that in taking any step at all, officials should look at the range of likely consequences. Of course it is possible that a full assessment of such consequences will be beyond existing capacities. In such cases simplifying devices might be helpful. See Goklany, supra note, at 9-10, for some suggestions.
} 
as a precondition for regulation; the demand should be firmly resisted, because a probability of harm is, under many circumstances, a sufficient reason to act. Both individuals and societies have a tendency to neglect the future; the precautionary principle might be understood as a warning against that form of neglect. There are extremely good reasons to incorporate distributional considerations into risk regulation, and the precautionary principle seems, some of the time, to be a way to protect the most disadvantaged against risks of illness, accident, and death. Sometimes people try to reduce dissonance by thinking that actual risks are trivial; the precautionary principle might work as a helpful counterweight to this mechanism. The problem is that the precautionary principle, as applied, is a crude and sometimes perverse way to promote these various goals, not least because it might be, and has been, urged in situations in which the principle threatens to injure future generations and to harm rather than to help those who are most disadvantaged.

I have also urged that the precautionary principle can be made operational only because of identifiable cognitive mechanisms. Often loss aversion is at work. The benefits of certain practices are less salient than the costs, simply because the costs would, along an important dimension, represent a deterioration from the status quo. When loss aversion is involved, it might be thought, wrongly, that natural processes are always safer, and better for the environment, than processes that involve human intervention. Sometimes the precautionary principle works by exploiting the availability heuristic, because the risks that matter are cognitively accessible, whereas the risks that are ignored are far less so. Frequently the precautionary principle is underwritten by probability neglect. Highly speculative harms are emphasized by those who focus on the badness of the relevant outcomes, rather than the likelihood that they will occur. Most generally, the precautionary principle sometimes gives an illusion of guidance because people focus on the immediate risk while disregarding the systemic effects of one-shot interventions, even though those interventions can give rise to risks of their own.

I have not suggested any particular substitute for the precautionary principle. 
But I do not endorse the suggestion of Aaron Wildavsky, a political scientist with a special interest in risk regulation, who also rejects the precautionary principle. ${ }^{204}$ In Wildavsky's view, the notion of "precaution" should be abandoned and replaced with a principle of "resilience," based on an understanding that nature, and society, are quite able to incorporate even strong shocks, and that the ultimate dangers are therefore smaller than we are likely to fear. It would follow from the "resilience" principle that a nation should be less concerned than it now is with the risks associated with (for example) arsenic, global warming, and destruction of the ozone layer. Unfortunately, the principle of "resilience" is no better than that of "precaution." Some systems are resilient, but many are not. Whether an ecosystem, or a society, is "resilent" cannot be decided in the abstract. In any case resilience is a matter of degree. Everything depends on the facts. The "resilience principle" should be understood as a heuristic, one that favors inaction in the face of possibly damaging technological change. Like most heuristics, the resilience principle will work well in many circumstances, but it can also lead to systematic and even deadly errors. ${ }^{205}$

A better approach would acknowledge that a wide variety of adverse effects may come from inaction, regulation, and everything between. Such an approach would attempt to consider all of those adverse effects, not simply a subset. ${ }^{206}$ When existing knowledge does not allow clear assessments of the full range of adverse effects, such an approach would develop simplifying devices, helping to show the appropriate course of action in the face of uncertainty. ${ }^{207}$ Such an approach would pursue distributional goals

\footnotetext{
${ }^{204}$ See Aaron Wildavsky, But Is It True? A Citizen's Guide to Environmental Health and Safety Issues 433 (1995).

${ }^{205}$ Cf. See Amos Tversky and Daniel Kahneman, Judgment Under Uncertainty: Heuristics and Biases, in Judgment and Decision Making: A Interdisciplinary Reader 38, 55 (Hal Arkes and Kenneth Hammond). (emphasizing that heuristic can lead to systematic mistakes). The resilience principle might well be taken as a reflection of optimistic bias. See Neil Weinstein, Unrealistic Optimism About Future Life Events, 39 J. Personality and Soc Psych. 806 (1980); Shelly Taylor, Positive Illusions (1991).

${ }^{206}$ See Wiener, supra note; Cass R. Sunstein, Risk and Reason (forthcoming 2002).

${ }^{207}$ See Goklany, supra note, at 9-10. Instead of advocating full-fledged balancing of relevant variables, Goklany proposes that regulators look at a list of criteria, including "the human mortality criterion" (valuing human life over that of members of other species), "the immediacy criterion" (giving priority to immediate threats), "the uncertainty criterion" (giving priority to risks with a higher probability of occurring), and "the irreversibility criterion" (giving priority to risks that are likely to be permanent or persistent). Some of these criteria seem to me doubtful; a less immediate threat might, for example, deserve priority if its magnitude so suggests, and it is unclear that a small number of human lives deserve priority
} 
directly by, for example, requiring wealthy countries, major contributors to the problem of global warming, to pay poor countries to reduce greenhouse gases or to prepare themselves for the relevant risks. And such an approach would attempt to counteract, rather than to embody, the various cognitive limitations that people face in thinking about risks. An appreciation of the difficulties with the precautionary principle suggests the importance of overcoming cognitive limitations by ensuring that people have a full, rather than limited, sense of what is at stake. The result should be to help with cognitive distortions and to produce sensible priority-setting. An effort to produce a fair accounting of the universe of dangers should also help to diminish the danger of interest-group manipulation.

To be sure, public alarm, even if ill-informed, is itself a harm, and it is likely to lead to additional harms, perhaps in the form of large-scale "ripple effects." ${ }^{208}$ A sensible approach to risk will attempt to reduce public fear even if it is baseless. My goal here has been not to deny that point, but to explain the otherwise puzzling appeal of the precautionary principle and to isolate the strategies that help make it operational. At the individual level, these strategies are hardly senseless, especially for people who lack much information or who do the best they can by focussing on only one aspect of the situation at hand. ${ }^{209}$ But for governments, the precautionary principle is not sensible, for the simple reason that once the viewscreen is widened, it become clear that the principle provides no guidance at all. A rational system of risk regulation certainly takes precautions. But it does not adopt the precautionary principle.

over a large number of lives of members of other species. But Goklany is correct to seek an approach that helps in making decisions under uncertainty. Wiener, supra note, offers some valuable suggestions, involving in partcular the need to ensure "risk-superior moves," meaning approaches that reduce overall risks. (Unpublished manuscript at 16.) The problem with this approach is that sometimes we will lack sufficient information to identify such moves, because regulation must proceed in the face of uncertainty rather than risk. See above.

${ }^{208}$ See the discussion of the social amplification of risk in Slovic, supra note.

${ }^{209}$ See Gerd Gigerenzer et al., Simple Heuristics That Make Us Smart (1999). 
Readers with comments may address them to:

Cass R. Sunstein

University of Chicago Law School

1111 East 60th Street

Chicago, IL 60637

csunstei@midway.uchicago.edu 


\section{Chicago Working Papers in Law and Economics}

(Second Series)

1. Willam M. Landes, Copyright Protection of Letters, Diaries, and Other Unbpublished Works: An Economic Approach (July 1991)

2. Richard A. Epstein, The Path to The T. J. Hooper: The Theory and History of Custom in the Law of Tort (August 1991)

3. Cass R. Sunstein, On Property and Constitutionalism (September 1991)

4. Richard A. Posner, Blackmail, Privacy, and Freedom of Contract (February 1992)

5. Randal C. Picker, Security Interests, Misbehavior, and Common Pools (February 1992)

6. Tomas J. Philipson \& Richard A. Posner, Optimal Regulation of AIDS (April 1992)

7. Douglas G. Baird, Revisiting Auctions in Chapter 11 (April 1992)

8. William M. Landes, Sequential versus Unitary Trials: An Economic Analysis (July 1992)

9. William M. Landes \& Richard A. Posner, The Influence of Economics on Law: A Quantitative Study (August 1992)

10. Alan O. Sykes, The Welfare Economics of Immigration Law: A Theoretical Survey With An Analysis of U.S. Policy (September 1992)

11. Douglas G. Baird, 1992 Katz Lecture: Reconstructing Contracts (November 1992)

12. Gary S. Becker, The Economic Way of Looking at Life (January 1993)

13. J. Mark Ramseyer, Credibly Committing to Efficiency Wages: Cotton Spinning Cartels in Imperial Japan (March 1993)

14. Cass R. Sunstein, Endogenous Preferences, Environmental Law (April 1993)

15. Richard A. Posner, What Do Judges and Justices Maximize? (The Same Thing Everyone Else Does) (April 1993)

16. Lucian Arye Bebchuk and Randal C. Picker, Bankruptcy Rules, Managerial Entrenchment, and Firm-Specific Human Capital (August 1993)

17. J. Mark Ramseyer, Explicit Reasons for Implicit Contracts: The Legal Logic to the Japanese Main Bank System (August 1993)

18. William M. Landes and Richard A. Posner, The Economics of Anticipatory Adjudication (September 1993)

19. Kenneth W. Dam, The Economic Underpinnings of Patent Law (September 1993)

20. Alan O. Sykes, An Introduction to Regression Analysis (October 1993)

21. Richard A. Epstein, The Ubiquity of the Benefit Principle (March 1994)

22. Randal C. Picker, An Introduction to Game Theory and the Law (June 1994)

23. William M. Landes, Counterclaims: An Economic Analysis (June 1994)

24. J. Mark Ramseyer, The Market for Children: Evidence from Early Modern Japan (August 1994)

25. Robert H. Gertner and Geoffrey P. Miller, Settlement Escrows (August 1994)

26. Kenneth W. Dam, Some Economic Considerations in the Intellectual Property Protection of Software (August 1994)

27. Cass R. Sunstein, Rules and Rulelessness, (October 1994) 
28. David Friedman, More Justice for Less Money: A Step Beyond Cimino (December 1994)

29. Daniel Shaviro, Budget Deficits and the Intergenerational Distribution of Lifetime Consumption (January 1995)

30. Douglas G. Baird, The Law and Economics of Contract Damages (February 1995)

31. Daniel Kessler, Thomas Meites, and Geoffrey P. Miller, Explaining Deviations from the Fifty Percent Rule: A Multimodal Approach to the Selection of Cases for Litigation (March 1995)

32. Geoffrey P. Miller, Das Kapital: Solvency Regulation of the American Business Enterprise (April 1995)

33. Richard Craswell, Freedom of Contract (August 1995)

34. J. Mark Ramseyer, Public Choice (November 1995)

35. Kenneth W. Dam, Intellectual Property in an Age of Software and Biotechnology (November 1995)

36. Cass R. Sunstein, Social Norms and Social Roles (January 1996)

37. J. Mark Ramseyer and Eric B. Rasmusen, Judicial Independence in Civil Law Regimes: Econometrics from Japan (January 1996)

38. Richard A. Epstein, Transaction Costs and Property Rights: Or Do Good Fences Make Good Neighbors? (March 1996)

39. Cass R. Sunstein, The Cost-Benefit State (May 1996)

40. William M. Landes and Richard A. Posner, The Economics of Legal Disputes Over the Ownership of Works of Art and Other Collectibles (July 1996)

41. John R. Lott, Jr. and David B. Mustard, Crime, Deterrence, and Right-to-Carry Concealed Handguns (August 1996)

42. Cass R. Sunstein, Health-Health Tradeoffs (September 1996)

43. G. Baird, The Hidden Virtues of Chapter 11: An Overview of the Law and Economics of Financially Distressed Firms (March 1997)

44. Richard A. Posner, Community, Wealth, and Equality (March 1997)

45. William M. Landes, The Art of Law and Economics: An Autobiographical Essay (March 1997)

46. Cass R. Sunstein, Behavioral Analysis of Law (April 1997)

47. John R. Lott, Jr. and Kermit Daniel, Term Limits and Electoral Competitiveness: Evidence from California's State Legislative Races (May 1997)

48. Randal C. Picker, Simple Games in a Complex World: A Generative Approach to the Adoption of Norms (June 1997)49. Richard A. Epstein, Contracts Small and Contracts Large: Contract Law through the Lens of Laissez-Faire (August 1997)

50. Cass R. Sunstein, Daniel Kahneman, and David Schkade, Assessing Punitive Damages (with Notes on Cognition and Valuation in Law) (December 1997)

51. William M. Landes, Lawrence Lessig, and Michael E. Solimine, Judicial Influence: A Citation Analysis of Federal Courts of Appeals Judges (January 1998)

52. John R. Lott, Jr., A Simple Explanation for Why Campaign Expenditures are Increasing: The Government is Getting Bigger (February 1998) 
53. Richard A. Posner, Values and Consequences: An Introduction to Economic Analysis of Law (March 1998)

54. Denise DiPasquale and Edward L. Glaeser, Incentives and Social Capital: Are Homeowners Better Citizens? (April 1998)

55. Christine Jolls, Cass R. Sunstein, and Richard Thaler, A Behavioral Approach to Law and Economics (May 1998)

56. John R. Lott, Jr., Does a Helping Hand Put Others At Risk?: Affirmative Action, Police Departments, and Crime (May 1998)

57. Cass R. Sunstein and Edna Ullmann-Margalit, Second-Order Decisions (June 1998)

58. Jonathan M. Karpoff and John R. Lott, Jr., Punitive Damages: Their Determinants, Effects on Firm Value, and the Impact of Supreme Court and Congressional Attempts to Limit Awards (July 1998)

59. Kenneth W. Dam, Self-Help in the Digital Jungle (August 1998)

60. John R. Lott, Jr., How Dramatically Did Women's Suffrage Change the Size and Scope of Government? (September 1998)

61. Kevin A. Kordana and Eric A. Posner, A Positive Theory of Chapter 11 (October 1998)

62. David A. Weisbach, Line Drawing, Doctrine, and Efficiency in the Tax Law (November 1998)

63. Jack L. Goldsmith and Eric A. Posner, A Theory of Customary International Law (November 1998)

64. John R. Lott, Jr., Public Schooling, Indoctrination, and Totalitarianism (December 1998)

65. Cass R. Sunstein, Private Broadcasters and the Public Interest: Notes Toward A "Third Way" (January 1999)

66. Richard A. Posner, An Economic Approach to the Law of Evidence (February 1999)

67. Yannis Bakos, Erik Brynjolfsson, Douglas Lichtman, Shared Information Goods (February 1999)

68. Kenneth W. Dam, Intellectual Property and the Academic Enterprise (February 1999)

69. Gertrud M. Fremling and Richard A. Posner, Status Signaling and the Law, with Particular Application to Sexual Harassment (March 1999)

70. Cass R. Sunstein, Must Formalism Be Defended Empirically? (March 1999)71. Jonathan M. Karpoff, John R. Lott, Jr., and Graeme Rankine, Environmental Violations, Legal Penalties, and Reputation Costs (March 1999)

72. Matthew D. Adler and Eric A. Posner, Rethinking Cost-Benefit Analysis (April 1999)

73. John R. Lott, Jr. and William M. Landes, Multiple Victim Public Shooting, Bombings, and Right-to-Carry Concealed Handgun Laws: Contrasting Private and Public Law Enforcement (April 1999) 
74. Lisa Bernstein, The Questionable Empirical Basis of Article 2's Incorporation Strategy: A Preliminary Study (May 1999)

75. Richard A. Epstein, Deconstructing Privacy: and Putting It Back Together Again (May 1999)

76. William M. Landes, Winning the Art Lottery: The Economic Returns to the Ganz Collection (May 1999)

77. Cass R. Sunstein, David Schkade, and Daniel Kahneman, Do People Want Optimal Deterrence? (June 1999)

78. Tomas J. Philipson and Richard A. Posner, The Long-Run Growth in Obesity as a Function of Technological Change (June 1999)

79. David A. Weisbach, Ironing Out the Flat Tax (August 1999)

80. Eric A. Posner, A Theory of Contract Law under Conditions of Radical Judicial Error (August 1999)

81. David Schkade, Cass R. Sunstein, and Daniel Kahneman, Are Juries Less Erratic than Individuals? Deliberation, Polarization, and Punitive Damages (September 1999)

82. Cass R. Sunstein, Nondelegation Canons (September 1999)

83. Richard A. Posner, The Theory and Practice of Citations Analysis, with Special Reference to Law and Economics (September 1999)

84. Randal C. Picker, Regulating Network Industries: A Look at Intel (October 1999)

85. Cass R. Sunstein, Cognition and Cost-Benefit Analysis (October 1999)

86. Douglas G. Baird and Edward R. Morrison, Optimal Timing and Legal Decisionmaking: The Case of the Liquidation Decision in Bankruptcy (October 1999)

87. Gertrud M. Fremling and Richard A. Posner, Market Signaling of Personal Characteristics (November 1999)

88. Matthew D. Adler and Eric A. Posner, Implementing Cost-Benefit Analysis When Preferences Are Distorted (November 1999)

89. Richard A. Posner, Orwell versus Huxley: Economics, Technology, Privacy, and Satire (November 1999)

90. David A. Weisbach, Should the Tax Law Require Current Accrual of Interest on Derivative Financial Instruments? (December 1999)

91. Cass R. Sunstein, The Law of Group Polarization (December 1999)

92. Eric A. Posner, Agency Models in Law and Economics (January 2000)

93. Karen Eggleston, Eric A. Posner, and Richard Zeckhauser, Simplicity and Complexity in Contracts (January 2000)

94. Douglas G. Baird and Robert K. Rasmussen, Boyd's Legacy and Blackstone's Ghost (February 2000)

95. David Schkade, Cass R. Sunstein, Daniel Kahneman, Deliberating about Dollars: The Severity Shift (February 2000)

96. Richard A. Posner and Eric B. Rasmusen, Creating and Enforcing Norms, with Special Reference to Sanctions (March 2000) 
97. Douglas Lichtman, Property Rights in Emerging Platform Technologies (April 2000)

98. Cass R. Sunstein and Edna Ullmann-Margalit, Solidarity in Consumption (May 2000)

99. David A. Weisbach, An Economic Analysis of Anti-Tax Avoidance Laws (May 2000)

100. Cass R. Sunstein, Human Behavior and the Law of Work (June 2000)

101. William M. Landes and Richard A. Posner, Harmless Error (June 2000)

102. Robert H. Frank and Cass R. Sunstein, Cost-Benefit Analysis and Relative Position (August 2000)

103. Eric A. Posner, Law and the Emotions (September 2000)

104. Cass R. Sunstein, Cost-Benefit Default Principles (October 2000)

105. Jack Goldsmith and Alan Sykes, The Dormant Commerce Clause and the Internet (November 2000)

106. Richard A. Posner, Antitrust in the New Economy (November 2000)

107. Douglas Lichtman, Scott Baker, and Kate Kraus, Strategic Disclosure in the Patent System (November 2000)

108. Jack L. Goldsmith and Eric A. Posner, Moral and Legal Rhetoric in International Relations: A Rational Choice Perspective (November 2000)

109. William Meadow and Cass R. Sunstein, Statistics, Not Experts (December 2000)

110. Saul Levmore, Conjunction and Aggregation (December 2000)

111. Saul Levmore, Puzzling Stock Options and Compensation Norms (December 2000)

112. Richard A. Epstein and Alan O. Sykes, The Assault on Managed Care: Vicarious Liability, Class Actions and the Patient's Bill of Rights (December 2000)

113. William M. Landes, Copyright, Borrowed Images and Appropriation Art: An Economic Approach (December 2000)

114. Cass R. Sunstein, Switching the Default Rule (January 2001)

115. George G. Triantis, Financial Contract Design in the World of Venture Capital (January 2001)

116. Jack Goldsmith, Statutory Foreign Affairs Preemption (February 2001)

117. Richard Hynes and Eric A. Posner, The Law and Economics of Consumer Finance (February 2001)

118. Cass R. Sunstein, Academic Fads and Fashions (with Special Reference to Law) (March 2001)

119. Eric A. Posner, Controlling Agencies with Cost-Benefit Analysis: A Positive Political Theory Perspective (April 2001)

120. Douglas G. Baird, Does Bogart Still Get Scale? Rights of Publicity in the Digital Age (April 2001)

121. Douglas G. Baird and Robert K. Rasmussen, Control Rights, Priority Rights and the Conceptual Foundations of Corporate Reorganization (April 2001)

122. David A. Weisbach, Ten Truths about Tax Shelters (May 2001) 
123. William M. Landes, What Has the Visual Arts Rights Act of 1990 Accomplished? (May 2001)

124. Cass R. Sunstein, Social and Economic Rights? Lessons from South Africa (May 2001)

125. Christopher Avery, Christine Jolls, Richard A. Posner, and Alvin E. Roth, The Market for Federal Judicial Law Clerks (June 2001)

126. Douglas G. Baird and Edward R. Morrison, Bankruptcy Decision Making (June 2001)

127. Cass R. Sunstein, Regulating Risks after ATA (June 2001)

128. Cass R. Sunstein, The Laws of Fear (June 2001)

129. Richard A. Epstein, In and Out of Public Solution: The Hidden Perils of Property Transfer (July 2001)

130. Randal C. Picker, Pursuing a Remedy in Microsoft: The Declining Need for Centralized Coordination in a Networked World (July 2001)

131. Cass R. Sunstein, Daniel Kahneman, David Schkade, and Ilana Ritov, Predictably Incoherent Judgments (July 2001)

132. Eric A. Posner, Courts Should Not Enforce Government Contracts (August 2001)

133. Lisa Bernstein, Private Commercial Law in the Cotton Industry: Creating Cooperation through Rules, Norms, and Institutions (August 2001)

134. Richard A. Epstein, The Allocation of the Commons:Parking and Stopping on the Commons (August 2001)

135. Cass R. Sunstein, The Arithmetic of Arsenic (September 2001)

136. Eric A. Posner, Richard Hynes, and Anup Malani, The Political Economy of Property Exemption Laws (September 2001)

137. Eric A. Posner and George G. Triantis, Covenants Not to Compete from an Incomplete Contracts Perspective (September 2001)

138. Cass R. Sunstein, Probability Neglect: Emptions, Worst Cases, and Law (November 2001)

139. Randall S. Kroszner and Philip E. Strahan, Throwing Good Money after Bad? Board Connections and Conflicts in Bank Lending (December 2001)

140. Alan O. Sykes, TRIPs, Pharmaceuticals, Developing Countries, and the Doha "Solution" (February 2002)

141. Edna Ullmann-Margalit and Cass R. Sunstein, Inequality and Indignation (February 2002)

142. Daniel N. Shaviro and David A. Weisbach, The Fifth Circuit Gets It Wrong in Compaq v. Commissioner (February 2002) (Published in Tax Notes, January 28, 2002)

143. Warren F. Schwartz and Alan O. Sykes, The Economic Structure of Renegotiation and Dispute Resolution in the WTO/GATT System (March 2002, forthcoming Journal of Legal Studies 2002)

144. Richard A. Epstein, HIPAA on Privacy: Its Unintended and Intended Consequences (March 2002, forthcoming Cato Journal, summer 2002) 
145. David A. Weisbach, Thinking Ouside the Little Boxes (March 2002, forthcoming Texas Law Review)

146. Eric A. Posner, Economic Analysis of Contract Law after Three Decades: Success or Failure (March 2002)

147. Randal C. Picker, Copyright as Entry Policy: The Case of Digital Distribution (April 2002, forthcoming The Antitrust Bulletin)

148. David A. Weisbach, Taxes and Torts in the Redistribution of Income (April 2002, Coase Lecture February 2002)

149. Cass R. Sunstein, Beyond the Precautionary Principle (April 2002, updated January 2003) 